\title{
Coronaviridae: a review of coronaviruses and toroviruses
}

\author{
Dave Cavanagh \\ Institute for Animal Health, Compton Laboratory, High Street, Compton, Newbury RG20 7NN, \\ $U K$
}

\section{Introductory remarks}

From rags to riches, pauper to princess. Thus did Cinderella progress, literally overnight (well, three nights; Grimm \& Grimm http://www.nationalgeographic.com/grimm/index $2 . \mathrm{html}$ ). Coronaviruses were described as being a "virology backwater", the SARS coronavirus (SARS-CoV; severe acute respiratory syndrome) likened to Cinderella, thrusting coronaviruses from the shadows to the spotlight in early 2003. Understandably, this is the view from a human disease standpoint; coronaviruses in humans are usually considered to be the cause of nothing more serious than the common cold. However, this group of viruses has long had a higher profile in the veterinary science field, most of our knowledge of coronaviruses being based on viruses of domesticated species - plus the mouse (Tab. 1). Most of the 40000000000 chickens in the world annually succumb to infection by avian infectious bronchitis coronavirus (IBV), resulting in reduced production, including mortality. The death toll amongst newborn swine can be $90 \%$ when infected with porcine transmissible gastroenteritis coronavirus (TGEV). The names porcine haemagglutinating encephalomyelitis coronavirus (HEV) and porcine epidemic diarrhoea coronavirus (PEDV) tell their own story. Most of the coronaviruses replicate, at least initially, in either or both of the respiratory or enteric tracts (Tab. 1). Within a coronavirus species some variants may have a tropism for the respiratory tract, others for the enteric region, though usually causing pathology in only one of these regions. SARS-CoV might be an exception to this, it appearing to cause pathology in both tracts, although that might be strain dependent.

The advent of SARS-CoV served as a reminder of an important aspect that we already knew about coronaviruses, namely that their host range is greater than was often supposed. One of the human coronaviruses, human coronavirus-OC43, is extremely similar genetically to bovine coronavirus $(\mathrm{BCoV})$, suggesting that these viruses might be capable of infecting each other's recognised host. BCoV, under experimental conditions at least, infects and causes disease in turkeys. Canine enteric coronavirus (CECoV) 
Table 1. Species within the genera Coronavirus and Torovirus

\begin{tabular}{|c|c|c|c|c|}
\hline $\begin{array}{l}\text { Major } \\
\text { host }\end{array}$ & Virus species & Acronym & $\begin{array}{l}\text { Dominant } \\
\text { pathology }\end{array}$ & $\begin{array}{l}\text { Additional } \\
\text { hosts }\end{array}$ \\
\hline \multicolumn{5}{|c|}{ Coronavirus genus } \\
\hline \multicolumn{5}{|c|}{ Group 1} \\
\hline Swine & $\begin{array}{l}\text { - Porcine transmissible gastro- } \\
\text { enteritis virus }\end{array}$ & TGEV & Enteric ${ }^{a}$ & \\
\hline $\mathrm{Cat}^{\mathrm{c}}$ & Feline coronavirus & $\mathrm{FCoV}$ & $\begin{array}{l}\text { Enteric; } \\
\text { peritonitis }\end{array}$ & $\begin{array}{l}\operatorname{Dog}^{b} \\
\text { Swine }\end{array}$ \\
\hline Dog & $\square$ Canine enteric coronavirus & $\mathrm{CECoV}$ & Enteric & $\begin{array}{l}\mathrm{Cat}^{\mathrm{b}} \\
\text { Swine }^{\mathrm{b}}\end{array}$ \\
\hline Swine & $\begin{array}{l}\text { - Porcine epidemic diarrhoea } \\
\text { coronavirus }\end{array}$ & PEDV & Enteric & \\
\hline Human & Human coronavirus 229E & $\begin{array}{l}\mathrm{HCoV}- \\
229 \mathrm{E}\end{array}$ & $\begin{array}{l}\text { Respiratory; } \\
\text { Enteric }^{\mathrm{d}}\end{array}$ & \\
\hline \multicolumn{5}{|c|}{ Group 2} \\
\hline Swine & $\begin{array}{l}\text { - Porcine haemagglutinating } \\
\text { encephalomyelitis coronavirus }\end{array}$ & $\mathrm{HEV}$ & $\begin{array}{l}\text { Central } \\
\text { nervous system }\end{array}$ & \\
\hline Cattle & Bovine coronavirus & $\mathrm{BCoV}$ & $\begin{array}{l}\text { Enteric or } \\
\text { respiratorye }\end{array}$ & $\begin{array}{l}\text { Turkey } \\
\text { Humans? }\end{array}$ \\
\hline Dog & $\square$ Canine respiratory coronavirus & $\mathrm{CRCoV}$ & Respiratory & \\
\hline Mouse & Murine hepatitis coronavirus & MHV & $\begin{array}{l}\text { Enteric, } \\
\text { Liver, } \mathrm{CNS}^{\mathrm{f}}\end{array}$ & $\mathrm{Rat}^{\mathrm{b}}$ \\
\hline Rat & Rat coronavirus & RtCoV & Sialodacryoadenitis & \\
\hline Puffin & Puffinosis coronavirus & $\mathrm{PuCoV}$ & puffinosis & \\
\hline Human & Human coronavirus OC43 & HCoV-OC43 & Respiratory $^{\mathrm{d}}$ & \\
\hline \multicolumn{5}{|c|}{ Group 3} \\
\hline Chicken & Infectious bronchitis coronavirus & IBV & $\begin{array}{l}\text { Respiratory } \\
\text { (kidney) }^{\mathrm{g}}\end{array}$ & \\
\hline Turkey & Turkey coronavirus & $\mathrm{TCoV}$ & Enteric & Chicken $^{\mathrm{b}}$ \\
\hline Pheasant & Pheasant coronavirus & $\mathrm{PhCoV}$ & $\begin{array}{l}\text { Respiratory } \\
{\text { (kidney })^{\mathrm{h}}}\end{array}$ & \\
\hline \multicolumn{5}{|c|}{ Group $4^{\mathrm{i}}$} \\
\hline Human & SARS-coronavirus & SARS-CoV & $\begin{array}{l}\text { Respiratory, } \\
\text { Enteric }\end{array}$ & $\begin{array}{l}\text { Civet cat } \\
\text { Raccoon } \\
\text { dog }^{\mathrm{j}} \\
\text { Other? }^{\mathrm{k}} \\
\text { Macaque }^{1} \\
\text { Cat }^{1, \mathrm{~m}}\end{array}$ \\
\hline
\end{tabular}

Torovirus genus

\begin{tabular}{llll} 
Swine & Porcine torovirus & PoToV & Enteric \\
Cattle & Bovine torovirus (Breda virus) & BToV & Enteric \\
Horse & Equine torovirus (Berne virus) & EqToV & Enteric \\
Human & Human torovirus & HToV & Enteric \\
\hline
\end{tabular}

aSome variants (often referred to as porcine respiratory coronavirus) of TGEV do not cause enteritis. They replicate largely asymptomatically in the respiratory tract

${ }^{\mathrm{b}}$ Deductions from experimental infections.

${ }^{\mathrm{c}}$ Apart from the domestic cat a similar virus has been isolated from a cheetah (Acinonyx jubatus) [261], in which it is widely detected [262]. 


\begin{abstract}
${ }^{\mathrm{d}}$ Although human coronaviruses have been shown to be associated with enteritis, their relatedness with the $\mathrm{HCoV} 229 \mathrm{E}$ and $\mathrm{HCoV}$ OC43 species has not been thoroughly investigated. ${ }^{\mathrm{e}}$ The classical $\mathrm{BCoVs}$ are associated with enteritis, though there are respiratory forms.

${ }^{\mathrm{f}}$ Central nervous system.

gNephritis is not uncommon, though not all chickens are observed to be affected in this way. Notwithstanding, some strains of IBV are highly nephropathogenic.

${ }^{\mathrm{h}}$ Nephritis has commonly been reported.

iSARS CoV has not been officially assigned to a group. It is placed here unofficially in a new group 4 , on the basis that its structural proteins have very low amino acid identity with those of groups 1,2 and 3, as is the case between viruses of groups 1,2 and 3 .

jVirus with $\sim 99.9 \%$ genome sequence identity with the human SARS-CoV was detected in these species. Also, there was serological evidence.

${ }^{k}$ There may be one or more other species of wild animal that is the natural host of SARS-CoV. ${ }^{1}$ Infected experimentally.

${ }^{\mathrm{m} C a t s}$ might have been involved in the spread of SARS in some episodes of the disease e.g. the Amoy Gardens incident, Hong Kong.

The symbols draw attention to hosts that are known to be infected by more than one species of coronavirus, including species from more than one coronavirus group.
\end{abstract}

can cause disease in swine and cats. Indeed, a subset of feline coronavirus $(\mathrm{FCoV})$ has been demonstrated to be a chimaera arising from recombination between an FCoV and CECoV. "Recombinant" was one of the spectres feared in the early weeks of the epidemic in Hong Kong. Subsequent sequencing of the genome has shown that SARS-CoV has not arisen by any recent recombination event. Notwithstanding, an appreciation of what has been learned from over half a century of studying coronaviruses helps to put SARS and SARS-CoV into perspective.

Delineating the roles of the various coronavirus proteins in pathogenesis and host range has been greatly facilitated by the development of procedures to make precise modifications to the coronavirus genome: targeted recombination for murine hepatitis virus (MHV) [1-4] and FCoV [1] and various "infectious clone" systems for HCoV-229E [5], TGEV [6, 7], IBV [73], MHV [8] and SARS-CoV [9]. Targeted recombination has been used to show that the gene order of MHV can be altered dramatically without reducing infectivity in vitro [10], demonstrating the plasticity of the coronavirus genome.

The family Coronaviridae comprises not only the genus Coronavirus but also Torovirus. Species in these two genera are morphologically very similar (Fig. 1), a prime reason for them being in the same family. Underlying this, they have similar structural proteins and overall genome organisation (Tab. 2). The Coronaviridae together with Arteriviridae and Okaviridae form the order Nidovirales, the members having some common features with respect to genome organisation, replication and transcription. The name Nidovirales is derived from the Latin nidus for nest, reflecting the large nested-set arrangement of the subgenomic mRNAs.

The first torovirus, Berne virus, now referred to as equine torovirus (EToV), was isolated in 1972, though no disease has been associated with it. 
coronavirus

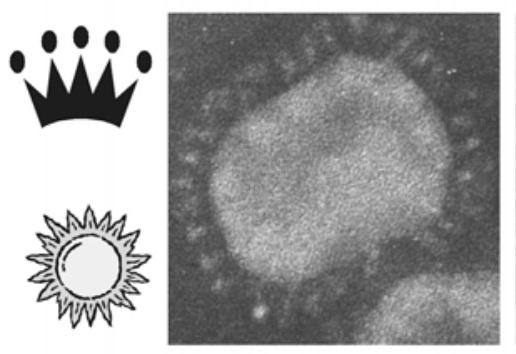

torovirus

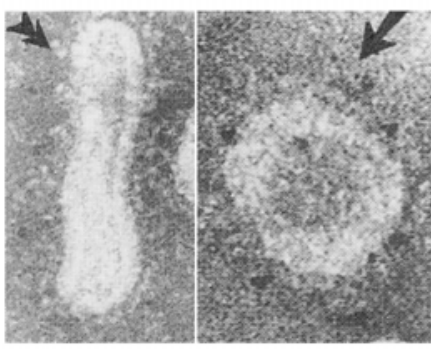

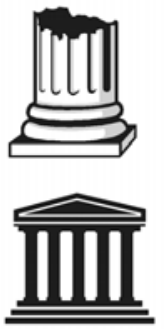

Figure 1. Appearance of a coronavirus (IBV) and torovirus (a human enteric ToV) by electron microscopy after negative staining. The appearance of coronaviruses was likened to that of some ornate crowns, the Latin for which is corona, and the corona of the sun, that also being derived from the Latin for crown, so corona was adopted for the name of this virus group. Toroviruses also derived their name from a Latin root, this time from torus, a semi-circular moulding such as is found at the base of a column. This name was chosen to reflect the appearance of the internal component of the virus which is torus- or doughnut-shaped (arrow). Some torovirus particles may appear rod-shaped (double arrowhead). Coronaviruses have a surface spike layer $(20 \mathrm{~nm})$ that may be more prominent than that of toroviruses. The shorter, $10 \mathrm{~nm}$, projections on the torovirus particles in these pictures may be the haemagglutinin esterase protein rather than the spike protein which may be largely absent. (Reprinted by Duckmanton et al., 1997, by permission from Elsevier.) [265]

Similar viruses may infect a number of ungulate species, as serology has indicated infections with EToV-like viruses in cattle, sheep, goats and pigs. About 10 years after the discovery of EToV, a torovirus was shown to be the cause of gastroenteritis in humans, with antigenic relationship to bovine torovirus (BToV).

Superficially toroviruses and coronaviruses resemble each other; one could be mistaken for the other during electron microscope analysis (Fig. 1).

The key dimension of this review is breadth rather than depth, its purpose being to set the stage for the proceeding chapters. References to more in-depth reviews are given throughout this chapter. As the remainder of this book is about SARS-CoV, the major part of this chapter is on the coronaviruses, much less on toroviruses. Indeed, much more is known about coronaviruses than toroviruses.

\section{Diseases in humans associated with coronaviruses and toroviruses}

Whilst there is insufficient space within this chapter for a thorough description of all coronavirus- and torovirus-induced diseases, the advent of SARS in humans makes it appropriate to summarise what we know about other diseases in humans caused by coronaviruses and toroviruses. 
Table 2. Features of coronaviruses and toroviruses

\begin{tabular}{lcc}
\hline Feature & Coronavirus & Torovirus \\
\hline Enveloped & + & + \\
Linear positive-sense ssRNA genome with poly(A) tail & + & + \\
5' polymerase gene-structural protein genes 3 & + & + \\
3' co-terminal nested set of $\geq$ 4 subgenomic mRNAs & + & + \\
Only the 5' unique region of an mRNA is translated & + & + \\
Polymerase gene has two ORFs, 1a and 1b & + & + \\
The 1b ORF is translated after ribosomal frameshifting & + & + \\
M protein has three membrane-spanning sequences & + & + \\
Virion formation at internal membranes & $27-31$ & \\
Genome size (kb) & + & + \\
5' leader sequence & + & Tubular \\
Core shell & Helical & + \\
Nucleocapsid (RNA plus N protein) & + & + \\
Prominent S glycoprotein. & + & \\
Coiled-coil structure in S protein & & + \\
\hline
\end{tabular}

Adapted from [263] and [264].

The reader is referred to [59] and [32] for more detail of torovirus proteins.

HCoVs are generally thought of in the context of the common cold, some $25 \%$ of which are believed to be caused by HCoVs [11, 12]. Subclinical or very mild infections are common and can occur throughout the year. In a study of children with otitis media with effusion, HCoVs were associated with $10 \%$ of them, respiratory syncytial virus being associated in approximately $30 \%$ of cases [13].

There have been some reports indicating a more serious lower respiratory tract involvement of HCoVs in young children and old people. It is not clear that $\mathrm{HCoVs}$ infect the lower respiratory tract but the occurrence of $\mathrm{HCoV}$ upper respiratory tract infections coupled with other factors, e.g. in immunocompromised people, may cause more serious disease, including pneumonia [14]. Up to $30 \%$ of acute wheezing episodes in asthmatic children may be due to coronavirus infection [15].

A study in a neonatal intensive care unit revealed that all premature infants infected with coronaviruses had symptoms of bradycardia, apnea, hypoxemia, fever or abdominal distention. Chest X-ray revealed diffuse infiltrates in two cases. In a study of nosocomial viral respiratory infections (NVRI) in neonates (up to one month of age) who had been hospitalised, it was concluded that the incidence of NVRI with common respiratory viruses was low, $\mathrm{HCoV}$ being the most important pathogen in NVRI in the study [16]. Elderly patients who had been hospitalised because of cardiopulmonary illnesses, and who tested negative for influenza and respiratory syncytial viruses, were examined further. Approximately $8 \%$ were identified as having either HCoV 229E or OC43 [17].

Infections with respiratory viruses, of which HCoVs are but one, are commonly associated with asthma exacerbation. Coronavirus was detected 
in approximately $5 \%$ of children [18] and $22 \%$ of adults hospitalised because of asthma [19]. Allergic patients with a common cold, associated with a number of viruses, including $\mathrm{HCoVs}(25 \%)$, had prolonged nasal eosinophil influx [20]. Whether that would increase the risk of subsequent allergen-induced hypersensitivity reactions is not known. In this regard it is perhaps worth noting that it has been suggested that the lung pathology observed in human SARS patients might be associated with immunopathology.

Evidence has increased that toroviruses are associated with gastroenteritis in humans. In a case-control study of children, an antigen capture ELISA revealed torovirus in stools from 27\% (9/33) of children with acute diarrhoea, 27\% (11/41) with persistent diarrhoea and none in controls [21]. Enteraggregative Escherichia coli was commonly found in assocation with the torovirus. In another childhood study, electron microscopy revealed a torovirus incidence of $35 \%(72 / 206)$ and $15 \%$ in gastroenteritis cases and controls, respectively [22].

\section{What it is to be a coronavirus or torovirus}

IBV was the first $\mathrm{CoV}$ to be isolated, in 1937, followed about 10 years later by MHV, human coronaviruses being discovered in the mid-1960s. These viruses had a common appearance when visualised with the electron microscope (Fig. 1). This confirmed that they were enveloped viruses, approximately $120 \mathrm{~nm}$ in diameter, and showed that they had large $(20 \mathrm{~nm})$, clubshaped surface projections (spike protein, S). Toroviruses also have $20 \mathrm{~nm}$ spikes. Whilst toroviruses might be seen having a doughnut-shaped internal component (Figs. 1 and 2), this is not always evident, the two types of virus then being easily confused.

When visualised in clinical specimens the quality of image is not always good.

Even with cell culture-grown virus some negatively-stained preparations reveal the spike layer of coronaviruses poorly. Indeed, some virus particles may actually have few spikes. The globular part of the S protein of IBV has a tendency to dissociate from the stalk [23, 24]. Various sedimentation studies have indicated that the mature $\mathrm{S}$ protein is a homodimer or homotrimer [25], homodimer [26, 27] or homotrimer [28]. It has two functions; to attach the virus to receptor molecules on host cells, and to activate fusion of the virion membrane with host cell membranes, to release the viral genome into the cell. The structure, variation and functions of the $\mathrm{S}$ protein have been reviewed [29-31].

Electron microscopy of BToV revealed few of the $20 \mathrm{~nm}$ spikes but rather an intact fringe of smaller spikes, some 7-9 $\mathrm{nm}$ in length [32-34]. Toroviruses isolated from human faeces had an intact fringe of $10 \mathrm{~nm}$ spikes [33] that resembled those seen on human toroviruses by Beards et al. [35]. 
coronavirus

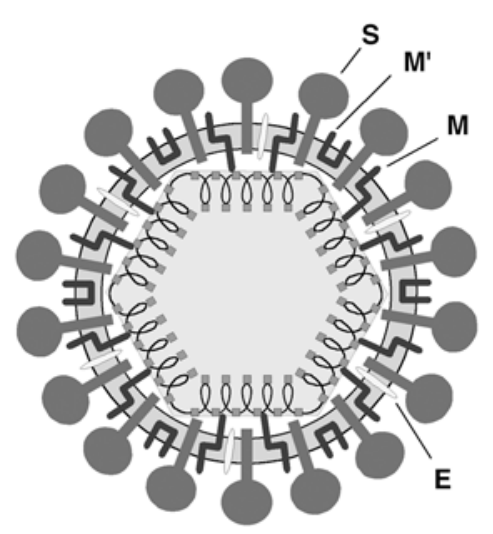

torovirus

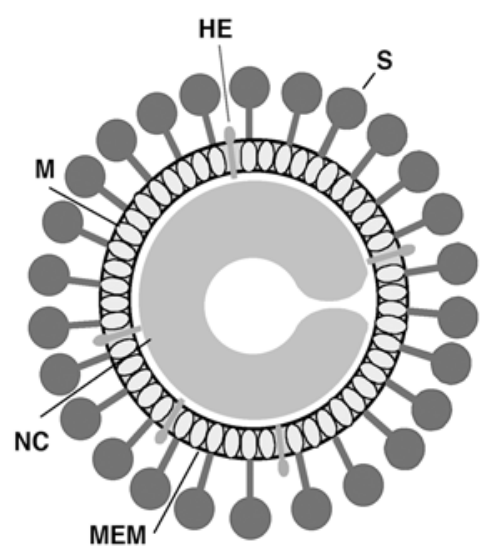

Figure 2. Diagrammatic representation of the virions of a coronavirus and a torovirus. Both types of virus have a lipid membrane (MEM), prominent $20 \mathrm{~nm}$ spike proteins (S) and an integral membrane protein (M). Group 2 coronaviruses, and some toroviruses, have an HE protein that forms a layer of $7 \mathrm{~nm}$ spikes (not shown). Coronaviruses, but not toroviruses, contain a small number of molecules of an E protein. Cryoelectron microscopy has indicated the presence of a core structure in coronaviruses, comprising a nucleocapsid (NC: N protein plus genomic RNA) and the carboxyterminal endodomain of the M protein (M). In TGEV some of the M molecules (M') have been shown to have both their N- and C-terminal parts on the outer surface of the virion. The nucleocapsid of toroviruses has the appearance of a torus (see Fig. 1). (Reprinted from González et al. 2003 [266] by permission from Springer.)

The latter reported observing the $20 \mathrm{~nm}$ spikes only rarely. It is possible that the $10 \mathrm{~nm}$ spikes are the haemagglutinin esterase (HE) protein. BToV has a HE protein that forms a fringe of spikes approximately $6 \mathrm{~nm}$ in length [32].

Apart from the $\mathrm{S}$ protein, all corona- and toroviruses have a smaller membrane glycoprotein (M; reviewed by Rottier [36]) and a protein closely associated with the RNA genome (to form a ribonucleoprotein, RNP), the nucleocapsid protein (N; reviewed by Laude and Masters [37]). The $\mathrm{N}$ protein of CoVs is much bigger than that of toroviruses (Tab. 3). Apart from giving some protection to the RNA genome, the $\mathrm{N}$ protein may also have roles in RNA replication and transcription, though this awaits demonstration. The $\mathrm{N}$ protein of both genera is phosphorylated.

Virions of coronaviruses have low amounts of a very small membraneassociated, non-glycoslyated protein, E (reviewd by Siddell [38]), which is not present in toroviruses (Tab. 3). The E and $\mathrm{M}$ proteins are essential for virus particle formation. Non-infectious virus-like particles can be formed in the absence of both the $\mathrm{S}$ and $\mathrm{N}$ proteins, but not if either $\mathrm{E}$ or $\mathrm{M}$ is missing $[39,40]$. 
Table 3. Viron-associated proteins of coronaviruses and toroviruses.

\begin{tabular}{llcc}
\hline Protein & & \multicolumn{2}{c}{$\begin{array}{c}\text { Apparent molecular weight in } \\
\text { SDS polyacrylamide gels (kDa) }\end{array}$} \\
& & Coronavirus & Torovirus \\
\hline Spike glycoprotein & $\mathrm{S}$ & $180-220$ & 200 \\
Integral membrane protein & $\mathrm{M}$ & $23-35$ & 27 \\
Small envelope protein & $\mathrm{E}$ & $9-12$ & Absent \\
Haemagglutinin-esterase protein & $\mathrm{HE}$ & 65 & 65 \\
Nucleocapsid protein & $\mathrm{N}$ & $50-60$ & 19 \\
\hline
\end{tabular}

Adapted from [264].

It is the $\mathrm{N}$ terminus of the $\mathrm{M}$ protein, of both coronaviruses and toroviruses, which is exposed at the outer virion surface. Only 20 amino acids or so are exposed, forming the ectodomain, in the case of the coronaviruses. The next $50 \%$ or so of the molecule is within the envelope, in the form of three membrane-spanning regions, the remaining, C-terminal, half of the molecule being partly membrane associated and partly within the lumen of the virion i.e. it is amphipathic [36, 41, 42]. Notwithstanding, studies with TGEV have revealed that approximately one-third of the $\mathrm{M}$ molecules have both the $\mathrm{N}$ - and $\mathrm{C}$-termini exposed at the outer virion surface [43]. The $\mathrm{M}$ protein of coronaviruses, but not toroviruses, is glycosylated.

The RNP released from virions had been observed by negative stain electron microscopy as a filamentous helical structure. For many years it was assumed that the RNP was largely independent of the other structural proteins, although probably interacting to some degree with the M protein prior to virus particle formation. Some light on the nature of this interaction has been shed by cryoelectron microscopic studies of TGEV. These have shown that extracellular, infectious coronavirus particles contain a core shell, probably icosahedral [44]. This comprises the RNP intimately associated with the $\mathrm{C}$-terminal half of the M protein [45-47]. This structure can be released intact from virions by appropriate detergents. During this extraction process, the $30 \%$ or so of the $\mathrm{M}$ molecules that had both their termini at the outer virus surface were released, i.e. were not associated with the core.

M protein molecules interact laterally with each other, through multiple contact sites, particularly in the transmembrane region $[48,49]$. The $\mathrm{M}$ protein also interacts non-covalently with sequences within the transmembrane region and short, C-terminal, endodomain of the $\mathrm{S}$ protein [50, 51]. Mutations to both the transmembrane and amphipathic domains of $\mathbf{M}$ interfered with the M-S interaction [52].

The $\mathrm{M}$ protein of coronaviruses has one or two glycans, $\mathrm{N}$-linked in the case of groups 1 and 3, O-linked in group 2, on the short externally exposed $\mathrm{N}$-terminal region. Although $\mathrm{MHV}$ has four potential glycosylation sites 
(serine and threonine residues) on the short ectodomain, only one of them is glycoslyated [53]. Glycosylation of $\mathrm{M}$ is not actually required for virus particle formation, as shown by the presence of non-glycosylated $\mathrm{M}$ within virions, and mutational analysis [48]. The E protein, which is required for the budding process that is part of virus particle formation, is produced in abundance within infected cells, though only a few molecules of E are within virus particles. It has been estimated that the molar ratios of the TGEV E:S:M proteins is 1:20:300 [54]. The E protein is an integral membrane protein, the N-terminal half being buried within the membrane, spanning the membrane once, possibly twice, the $\mathrm{C}$-terminus being within the lumen of virions $[55,56]$. Although there is an N-linked glycosylation site near the $\mathrm{N}$ terminus of the IBV E protein, it is not utilised [55]. Toroviruses do not have an E protein.

The group 2 coronaviruses and the toroviruses have an additional structural protein, the HE protein (reviewed by Brian et al. [57] ), which forms a layer of short surface projections of approximately $7 \mathrm{~nm}$ in length. The $\mathrm{HE}$ protein is a neuraminic-O-acetlyesterase. It hydrolyses the $9-\mathrm{O}$-acetylated sialic acid on erythrocytes, thereby reversing haemagglutination induced by $\mathrm{HE}$ or $\mathrm{S}$; thus $\mathrm{HE}$ is considered to be a receptor-destroying enzyme [31,58].

Whereas there is virtually no amino acid identity between the S, M and $\mathrm{N}$ proteins of the coronaviruses and toroviruses, there is $30 \%$ identity between the HE proteins [59]. Moreover, the HE proteins of the Coronaviridae have approximately $30 \%$ identity with the haemagglutinin esterase fusion (HEF) protein of influenza $\mathrm{C}$ virus. This coincidence is believed to have happened as a result of recombination. Whereas the HEF protein is cleaved into two subunits, the HE protein is not cleaved and lacks most of the C-terminal subunit of the HEF protein of influenza C.

Some of these features are summarised within Table 2, together with aspects of the genomes of Coronaviridae members that will be discussed later.

\section{Relationships amongst coronaviruses and toroviruses: structural proteins}

Coronaviruses have been assigned to three groups (Tab. 1). These were initially devised on the basis of a lack of antigenic relationships between the species of different groups [60]. Sequencing has largely confirmed these groupings, both in terms of amino acid identity and the sequence and location of the accessory non-structural proteins.

Thus within group 2 (MHV, RtCoV, BCoV, HCoV-OC43, for which sufficient sequence data is available) there is at least $61 \%$ amino acid identity when comparing the S, E, N and M proteins [61]). In group 3, comparing the E, $\mathrm{M}$ and $\mathrm{N}$ proteins, IBV and TCoV show identities of $\geq 80 \%$. Fewer genes 
of $\mathrm{PhCoV}$ have been sequenced, but comparison of the accessory proteins encoded by genes 3 and 5 also gave similar percentages.

Group 1 is less homogeneous. The trio of TGEV, CCoV and FCoV have S, E, N and M identities of $\geq 74 \%$. However, when HCoV 229E and PEDV are included, identities fall to between $23 \%$ (E protein) to $42 \%$ (S and $\mathrm{M}$ proteins). The S2 proteins of PEDV and $\mathrm{HCoV} 229 \mathrm{E}$ have $60 \%$ identity [62]. Thus PEDV and $\mathrm{HCoV} 229 \mathrm{E}$ are more related to each other than to the TGEV, CCoV and FCoV subgroup. Indeed, PEDV and HCoV 229E only just "squeeze in" to group 2 on the basis of gene sequences (Fig. 3). Comprehensive antigenic analysis reflects the sequence analysis within group 2 [63-65]. There are many common epitopes in the S, M and N proteins of TGEV, CCoV and $\mathrm{FCoV}$, but no antigenic cross-reaction between these and PEDV/HCoV 229E.

Immune electron microscopy has revealed relationships between the toroviruses of humans, equines and bovines [33, 35]. Much remains to be done to establish the extent of variation among human toroviruses. Viruses similar to EToV would seem to infect a number of ungulate species, as serology has indicated infections with EToV-like viruses in cattle, sheep, goats and pigs [66].

Relationships amongst coronaviruses and toroviruses: non-structural proteins and genome organisation

CoVs and ToVs have the general genome organisation:

5'UTR-polymerase gene - structural protein genes - UTR 3'

where the UTR are untranslated regions (each up to 500 nucleotides in coronaviruses). The structural protein genes of coronaviruses are in the order

(HE)-S-E-M-N

the HE gene only being in group 2 viruses. The corresponding gene order of toroviruses is

\section{S-M-HE-N}

where the $\mathrm{HE}$ is intact in EToV but a pseudogene in BToV [67].

In addition to sequence differences noted in the preceeding section, the coronaviruses differ with respect to genes that encode proteins that are not structural proteins, i.e. not present in virus particles. The viruses differ with respect to both the number and location of the non-structural protein genes and, in some cases, on the mode of translation of the proteins (Fig. 4; reviewed by Lai and Cavanagh [31]). The toroviruses do not have any nonstructural proteins other than those encoded by gene 1 . 


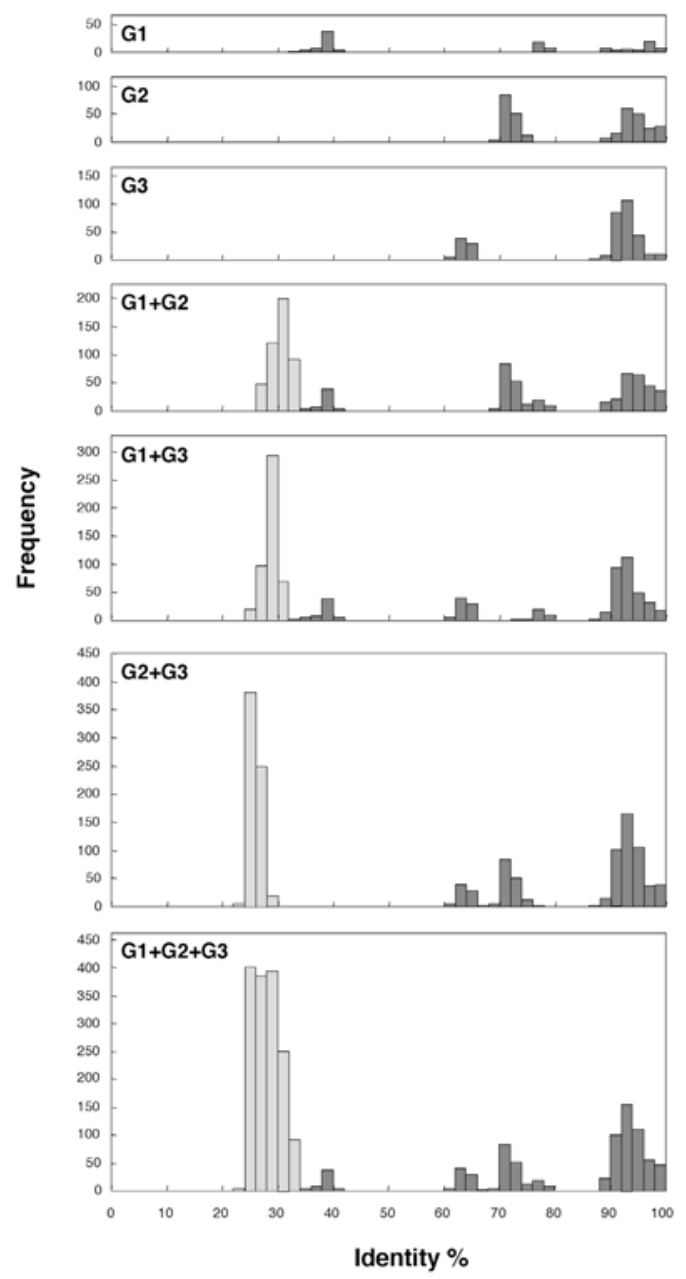

Figure 3. Protein sequence relationships within and between coronavirus groups 1, 2 and 3 (G1, G2 and G3) illustrated by the nucleocapsid protein. The Y-axis shows the frequency distribution of pairwise identity percentages of the $\mathrm{N}$ proteins. Histograms of the intra-group scores are in dark grey, those of inter-group scores in light grey. In group 1 the bars with an identity of $\sim 40 \%$ correspond to HCoV-229E and PEDV, whereas the other bars in group 1 correspond to TGEV, CECoV and $\mathrm{FCoV}$. In group 3 most of the data is for IBV isolates, the bars with an identity of $\sim 60 \%$ corresponding to a group of IBV strains isolated in Australia, significantly different from those isolated on other continents. (Reprinted from González et al. 2003, by permission from Springer.) [266]

Group $2 \mathrm{CoVs}$ are the only ones to have a non-structural protein gene between gene 1 (replicase gene) and the $\mathrm{S}$ protein gene. Adjacent to it is the gene encoding the HE structural (though non-essential) protein. In some strains of MHV, which have had multiple passages in vitro, the HE gene is 


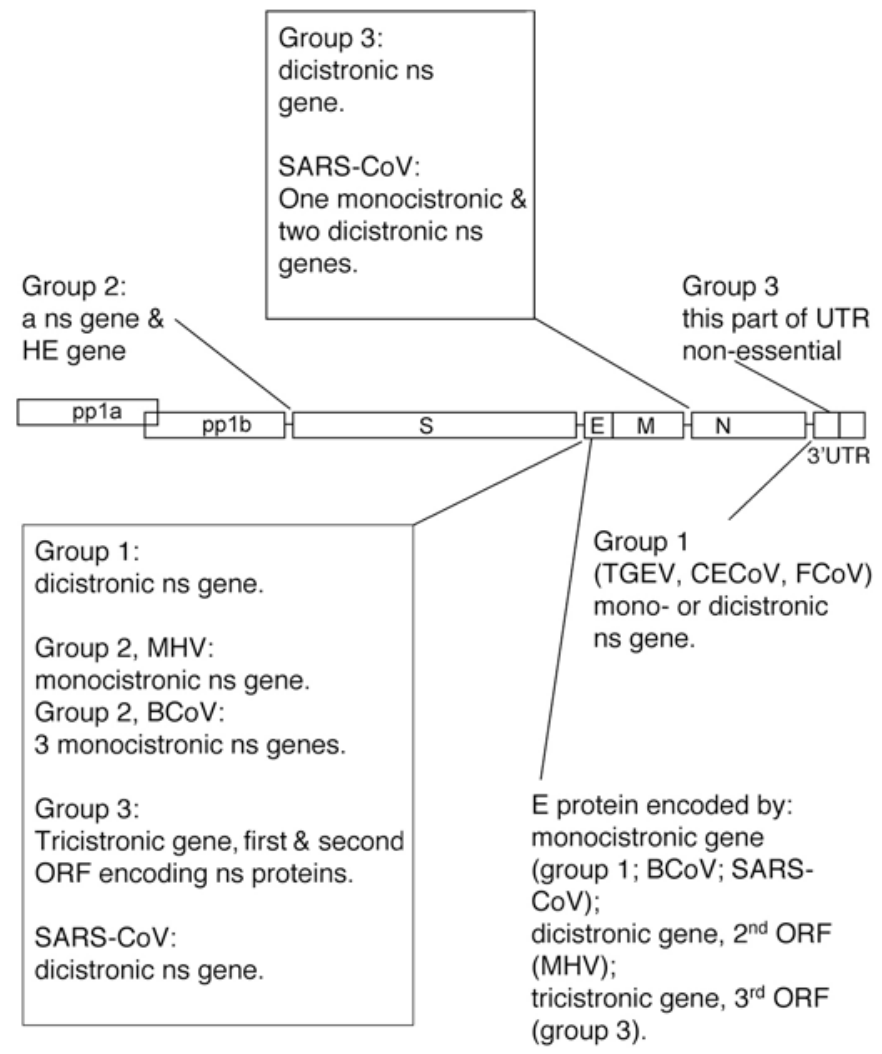

Figure 4. Genome organisation of coronaviruses. The "core" gene complement comprises the genes that encode essential proteins: gene 1, which encodes various proteins derived from polyproteins (pp) 1a and $1 \mathrm{~b}$, associated with RNA replication and transcription, and the S, E, $\mathrm{M}$ and $\mathrm{N}$ proteins, that are found in virus particles. Inserted between these genes, at the points shown, but varying amongst the coronaviruses, are "accessory" genes, which encode proteins that are non-structural (ns) and not essential for replication per se, i.e. not required for replication in vitro, but which are believed to have roles in host animals i.e. in vivo. Gene 1 is not to scale.

incomplete, i.e. it is a pseudogene. Hence such isolates do not have a HE protein in the virions.

All the coronaviruses have open reading frames (ORFs) between the $\mathrm{S}$ protein gene and the ORF encoding the $\mathrm{E}$ protein. In the case of group 1 and 2 viruses, and SARS-CoV, there is a gene before that encoding the $\mathrm{E}$ protein, where a gene means a sequence under the control of a transcription-associated sequence (TAS), which generates a mRNA. This gene may have one, two or three ORFs (Fig. 4). The E protein of group 1 viruses, and SARS-CoV, is encoded by a monocistronic gene, i.e. which encodes a sin- 
gle ORF. In the case of group 2 and 3 viruses, the E protein is encoded by the second and third ORF, of dicistronic and tricistronic genes, respectively.

In all cases (to date) the ORF encoding the $\mathrm{E}$ protein is followed by the $\mathrm{M}$ protein gene and, for groups 1 and 2, this is followed directly by the $\mathrm{N}$ protein gene. In contrast, group 3 viruses and SARS-CoV have one and three genes, respectively, encoding non-structural proteins located between the $\mathrm{M}$ and $\mathrm{N}$ protein genes (Fig. 4). Finally, TGEV, FCoV and $\mathrm{CECoV}$ have a non-structural protein gene (which is mono- or dicistronic) after the $\mathrm{N}$ protein gene. Interestingly, the part of the 3' UTR of gene 3 viruses that is adjacent to the $\mathrm{N}$ protein gene actually comprises an ORF, though there is no identifiable TAS sequence from which to generate an mRNA [68]. This part of the 3' UTR is not required for viability [69]. It is conceivable that at one time this ORF was part of a gene, encoding a non-structural protein, the TAS sequence having been lost.

\section{Roles of the non-structural proteins}

The roles of the non-structural proteins, other than those encoded by gene 1, are not known. Genetically manipulated TGEV [70, 71], MHV [10, 72] and IBV (our unpublished observations) from which the genes encoding these proteins have been deleted or inactivated replicate to more or less normal titres in vitro, i.e. in cell culture. Hence they are considered to be non-essential for replication. It is believed that they have roles in vivo i.e. within host animals, and have been called "accessory" genes [74]. Deletion of the accessory genes of MHV resulted in attenuation of pathogenicity, to the extent that the mutants were no longer lethal in mice [10]. This is not an inevitable consequence; deletion of the two non-structural protein ORFs of gene 3 of TGEV did not attenuate pathogenicity [75].

There is virtually no amino acid identity between the non-structural proteins of one coronavirus group and another and no identity with any noncoronavirus proteins in public databases. As one might imagine given that these proteins are not required for replication per se, there are variations within some coronavirus species, which tend to be associated with passage of the viruses in vitro. For example, some TGEV strains do not have intact ORFs in the gene that precedes the E protein gene. Propagation of SARS$\mathrm{CoV}$ in Vero cells [76] resulted in a 45-nucleotide, in-frame deletion from ORF7b. Most of the SARS-CoV isolates from humans in 2003 had a deletion of 29 nucleotides in gene 8, when compared to the isolates from Himalayan palm civet cats and raccoon dogs, and one of the earliest human isolates [77]. The consequence is that most of the human isolates had two ORFs within gene 8 , whereas the animal isolates had a single, longer ORF. Whether this has any functional significance for the pathogenicity of SARS-CoV in humans is not known. 


\section{Replication cycle}

Coronaviruses and toroviruses have positive-sense genomes; genomic RNA, once released from virions early in infection, acts as an mRNA for translation of gene 1, producing the polymerase. Thereafter this generates mRNAs from the other genes, from which all the other proteins are made. Consequently virions contain only structural proteins, unlike virions of negative-sense RNA viruses that contain proteins involved in RNA replication and transcription. Replication is within the cytoplasm.

\section{Initiation of infection: attachment to receptors}

It is the $\mathrm{S}$ protein that is responsible for attachment of the virus to host cell receptors, i.e. $S$ is the receptor binding protein. Popova and Zhang [78] have demonstrated that even for group 2 viruses, which have an HE protein, the $\mathrm{S}$ protein is sufficient for attachment leading to infection. Earlier Schultze et al. [79] had shown that the S protein of BCoV was more efficient at causing haemagglutination than the HE protein, and had proposed that $\mathrm{S}$ was the primary receptor-binding protein. Expression of several coronavirus $S$ proteins from various vectors has shown that it is the $S$ protein that induces membrane fusion, observed as syncytium formation, a prerequisite of which is attachment to a cell (reviewed by Lai and Cavanagh [31]. It is also the major inducer of virus-neutralizing and haemagglutination-inhibiting antibodies (reviewed by Cavanagh [29, 80]).

Cell surface molecules that act as receptors have been identified for MHV, a number of group 2 coronaviruses and, most recently, for SARS$\mathrm{CoV}$. The part of the $\mathrm{S}$ protein that is responsible for attachment to these receptors, the receptor-binding domain, has also been identified for these viruses (Fig. 5). Most studies have been done with in vitro material, i.e. cultured cells, as one would expect. In addition there have been some investigations with ex vivo material (gut tissue), plus earlier studies with red blood cells. These studies indicate that the attachment process in vivo might be more complex than is indicated by in vitro studies alone.

The cellular receptor for MHV is CEACAM 1, a member of the carcinoembryonic antigen (CEA) family of glycoproteins in the immunoglobulin superfamily (reviewed by Lai and Cavanagh, [31]). It is a 424-amino acid glycoprotein with four immunoglobulin-like domains (see Lewicki and Gallagher [26]. A soluble form of this protein has been crystallised and an atomic structure deduced [81].

Chen et al. [82] transfected COS-7 cells, which lack a functional receptor for MHV, with genes of human CEACAM and human biliary glycoprotein; the cells were then susceptible to MHV. Experiments with chimaeras of human and murine CEACAM proteins revealed that the immunoglobulin loop of human CEACAM conferred virus-binding specificity. Different 


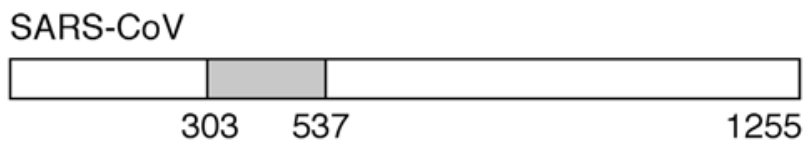

HCoV 229E

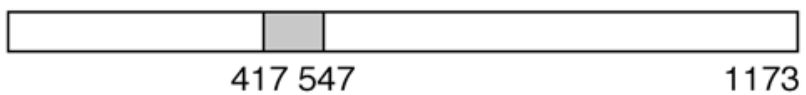

MHV

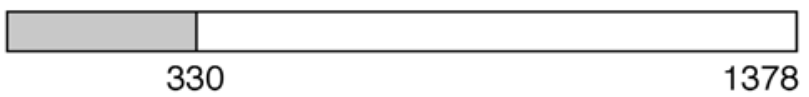

Figure 5. Regions (in grey) of S proteins of three coronaviruses that encompass a receptorbinding domain. The numbers denote amino acid residue positions.

isoforms of murine CEACAMs exist. These have extensive differences in the N-terminal immunoglobulin-like domain to which $\mathrm{MHV}$ binds and bind MHV to different extents. Analysis of chimaeras indicated that N-terminal amino acids 38-43 were key elements for binding MHV and activation of its fusion-inducing activity [83], subsequently confirmed [84]. Interestingly, when MHV had established a persistent infection in murine $17 \mathrm{Cl} 1$ cells, that express very low levels of the CEACAM 1 receptor, there was selection of mutant MHVs that were better able to use other molecules as receptors [85].

The receptor-binding domain of the MHV S protein is formed by sequence within the $330 \mathrm{~N}$-terminal amino acid residues of the S1 protein [86], though the stability of the interaction can be affected by downstream sequence [87] (Fig. 5).

Human aminopeptidase N (APN; also known as CD13) has been identified as a receptor for $\mathrm{HCoV}-229 \mathrm{E}$ [88]. This protein is a metalloprotease located on the surface of epithelial cells, including those of the intestine, lung and kidney. Human cells that were not susceptible to canine coronavirus $(\mathrm{CCoV})$ or $\mathrm{FCoV}$ became susceptible when transfected with a human/canine chimaera of APN [89]. The critical, C-terminal domain of the canine APN was formed by amino acids 643 to 841 .

The human and porcine APNs do not function as receptors for TGEV and HCoV 229E, respectively. When amino acids 255 to 348 of porcine APN were replaced by amino acids 260 to 353 of human APN, the resulting chimaeric protein was able to function as a receptor for $\mathrm{HCoV}-229 \mathrm{E}$ [90]. Kolb 
and colleagues [91] went on to show that the human cells became susceptible to FCoV, HCV 229E and TGEV when transfected with a cDNA of the feline APN. Analysis of chimaeric APNs showed that amino acids within the region 132-295 were involved in virus binding. Within this region was a hypervariable stretch of 8 amino acids. When these 8 residues in the porcine APN were replaced with the corresponding amino acids of HCoV 229E, the chimaeric receptor was able to bind $\mathrm{HCoV} 229 \mathrm{E}$. Human APN with five porcine APN residues from the corresponding region did bind HCV OC43 provided that a glycosylation site with the porcine residues was removed by mutation [92]. The authors concluded that certain differences in glycosylation between coronavirus receptors from different species are critical determinants in the species specificity of infection. Expression of feline APN in rodent cells rendered the cells susceptible not only to FCV but also to HCoV-229E, CCV and TGEV [88]. Various human neuronal and glial cell lines, which were susceptible to HCV 229E, expressed human APN, there being a correlation between the apparent amount of cell surface APN and the level of virus attachment [93].

Not only are there differences amongst APNs with respect to the binding of group 2 coronaviruses, there are also differences with respect to variants within a given coronavirus. Hohdatsu and colleagues [94] have shown that feline APN is a receptor for type II FCoV but not for type I. A monoclonal antibody to feline APN, which blocked infection of primary feline by type II FCoV, CECoV and TGEV did not block infection by type I FCoV. This antibody bound to APN that was recovered from feline intestinal brush-border membrane proteins. Type II FCoVs differ from type I in a number of ways, including that the $S$ protein would appear to have been derived from a FCoV by recombination [95].

Experiments using soluble truncated histidine-tagged S proteins, produced using baculovirus expression vectors, showed that the region of the HCoV-229E S protein from amino acids 417 to 547 was required for binding to its cell receptor [96] (Fig. 5).

The metallopeptidase, angiotensin-converting enzyme 2 (ACE2), on Vero cells has been shown to act as a receptor for SARS CoV [97]. The 293T cell type does not support efficient replication of SARS-CoV but did do so after being transfected with a cDNA expressing ACE2. It was the Nterminal half of the $\mathrm{S}$ protein that contained the receptor-binding domain for ACE2. This has been confirmed by Xiao et al. [98], who have shown that the receptor-binding domain of SARS-CoV is formed by residues between positions 303 and 537 (Fig. 5).

The enterotropism of TGEV is associated with the sialic acid-binding activity of the $\mathrm{S}$ protein. This virus recognises a mucin-type glycoprotein, in a sialic acid-dependent fashion, extracted from porcine intestinal brush border membranes [99]. The virus was observed to bind to mucin-producing goblet cells in cryosections of the small intestine of suckling piglets. A nonenteropathogenic mutant that did not have a sialic acid- 
binding activity was unable to bind to the mucin-type glycoprotein or to goblet cells.

Schultze and Herrler [100] had earlier shown that a vital component of the receptor for both the $\mathrm{S}$ and $\mathrm{HE}$ proteins of $\mathrm{BCoV}$ was the glycan component $\mathrm{N}$-acetyl-9-O-acetylneuraminic acid $\left(\mathrm{Neu} 5,9 \mathrm{Ac}_{2}\right)$. This residue acted as a receptor not only on erythrocytes but also on susceptible cell cultures. It has also been shown that cell surface sialoglycoproteins act as receptors for TGEV [101, 102]. Sialic acid residues also play a role in the haemagglutination of red blood cells by IBV, the necessary residue being $\alpha$ 2,3-linked $\mathrm{N}$-acetylneuraminic acid [103]. Attachment of coronaviruses might be a two-step (at least) process. Primary attachment might be mediated by a first receptor, e.g. Neu5,9 $\mathrm{Ac}_{2}$ for some coronaviruses, a second receptor e.g. APN or CEACAM proteins, bringing the virus and cell membranes closer together for subsequent membrane fusion. Some receptors might fulfil both functions for some coronaviruses. Although it can mediate binding to erythrocytes, the main function of HE might be to remove neuraminic acid from the virus and cell surface. The esterase activity of the HE, and HEF protein of influenza C, specifically cleaves $\mathrm{Neu} 5,9 \mathrm{Ac}_{2}$.

\section{Initiation of infection: membrane fusion to release the genome}

In order to release the genome into the cytoplasm the coronaviral envelope must fuse with a host cell membrane. This fusion event is brought about by regions in the S2, C-terminal part of the S protein, following attachment mediated by S1. Cleavage of the S polypeptide into $\mathrm{S} 1$ and $\mathrm{S} 2$ is not a prerequisite for infectivity, and fusion can occur at neutral $\mathrm{pH}$, suggesting that fusion can occur at the cell surface, although some variants require a lower $\mathrm{pH}$, indicating that they would be uncoated in endosomes (reviewed in [29-31]).

That the $\mathrm{S}$ protein alone is required for fusion has been demonstrated using viral vectors expressing $\mathrm{S}$ protein of $\mathrm{FCoV}$ and $\mathrm{MHV}$, at neutral $\mathrm{pH}$ [104-106]. Recombination experiments supported the view that S2 is responsible for the promotion of membrane fusion [107, 108]. The S2 polypeptide has a heptad repeat region (HR2) [109], adjacent to the transmembrane region (Fig. 6). There is a second heptad repeat region (HR1), located 170 amino acids upstream in MHV (Fig. 6). The HR2 consists of a leucine zipper motif, highly conserved amongst coronaviruses [110], which is a series of leucine residues repeated every seven amino acids. It is believed that the leucine zipper domain is essential for oligomerization of the S protein, which has a coiled-coil structure in S2 involved in membrane fusion [111,112] (Fig. 6). Mutations in this region cause defects in oligomerization and reduce fusion capability [113]. The HR1 contains a putative fusion peptide, involved in membrane fusion [114]. Bosch and colleagues 




Figure 6. Location of some of the structural features of the $\mathrm{S}$ protein of coronaviruses. The $\mathrm{S}$ protein of some coronaviruses is not cleaved into S1 and S2 glycopolypeptides; they do not have a basic connecting peptide. Hypervariable region 1 contains the putative fusion peptide responsible for membrane fusion.

[115] made polypeptides corresponding to HR1 (96 amino acids) and HR2 (39 amino acids) which, when mixed, assembled into a stable oligomeric alpha helical complex. The HR1 and HR2 polypeptides associated in an antiparallel fashion, forming $14.5 \mathrm{~nm}$ rod-like structures. This would bring the putative fusion peptide in HR1 into close proximity to the transmembrane region.

Components elsewhere in S2, or at least structures formed by other sequences in S2, can affect the fusion process. For example, some monoclonal antibodies that have anti-fusion activity are against epitopes near the N-terminal part of the S2 polypeptide [116,117]. It has been suggested that binding of these antibodies might destabilise the oligomeric structure of $\mathrm{S}$ and thereby interfere with the interaction of the fusogenic region with a cell membrane.

Lysosomotropic agents raise the $\mathrm{pH}$ in endosomes. If a virus requires a $\mathrm{pH}$ of $<7$ within endosomes for membrane fusion to occur, these agents prevent or reduce fusion, resulting in fewer cells being successfully infected. Some studies with these reagents led to the conclusion that uncoating of MHV occurs in endosomes (reviewed by [29, 31]). Other studies have shown little effect by these agents, and that the optimum $\mathrm{pH}$ for membrane fusion by MHV was $7.4[118,119]$. The productive infection of cells by the Beaudette strain of IBV was reduced by $90 \%$ by ammonium chloride, a lysosomotropic agent, and the optimum $\mathrm{pH}$ for cell-cell fusion (syncytium formation) was $\mathrm{pH}$ 6.7, indicating that uncoating occurs early after the start of endocytosis [120]. The same authors showed that the ammonium chloride had no effect on another strain of IBV, implying that fusion could occur 
at the cell surface. The SARS-CoV S protein caused syncytium formation at neutral $\mathrm{pH}[98]$.

As few as three amino acid changes in the heptad repeat regions of S2 of MHV resulted in virus that no longer fused optimally at $\mathrm{pH} 7.0$ but required acidic $\mathrm{pH}$ ( $\mathrm{pH}$ 5.5-6.0), and which was adversely affected by lysosomotropic agents [111, 121]. The variants of Gallagher and colleagues [111] had been recovered from a OBL21A neural cell line persistently infected with MHV i.e. the mutants had been selected by replication in this cell type. In conclusion, the weight of evidence is that the $\mathrm{S}$ proteins of most coronaviruses can cause membrane fusion a neutral $\mathrm{pH}$, suggesting that fusion of the virus can occur at the cell surface. Notwithstanding, some variants require an acidic $\mathrm{pH}$, indicating that they fuse with an endocytic membrane.

Binding of the $\mathrm{S}$ protein to a receptor causes conformational change in the $\mathrm{S}$ protein, promoting fusogenic activity $[26,122]$. Lewicki and Gallagher [26] produced soluble S1 fragments that were dimers. Binding of these dimers to the CEACAM receptor altered the confirmation of S1, generating alternative disulphide linkages within S1, and inducing separation of S1 and S2. This separation could happen for MHV S protein because, like other group 2 and group 3 coronaviruses, the $S$ protein is cleaved into two subunits, S1 and S2, which are non-covalently associated. Cleavage occurs adjacent to a connecting peptide region that contains one or more pairs of dibasic amino acids, e.g. RRFRR in many isolates of IBV, reviewed in [29, 31]. In some naturally occurring variants of IBV and MHV one of the basic residues has been replaced by histidine, which is weakly basic at neutral $\mathrm{pH}$. Zelus et al. [122] have also shown that the MHV spike protein undergoes conformational changes following binding to soluble receptor at $37^{\circ} \mathrm{C}$. The conformational change occurred not only with MHV S protein that was cleaved into $\mathrm{S} 1$ and $\mathrm{S} 2$ subunits, but also with a mutant whose $\mathrm{S}$ protein was not cleaved.

Initial experiments with MHV indicated that cleavage of $\mathrm{S}$ was required for its fusion activity. However, subsequent studies have shown that this is not the case but rather that cleaved $\mathrm{S}$ induces fusion more efficiently than uncleaved S [123, 124]. Variant MHVs selected in a persistently infected OBL21A neural cell line required low $\mathrm{pH}$ for fusion, in contrast to the wildtype virus. Whereas the latter had the connecting peptide RRAHR, the variants had RRADR, i.e. with an acidic aspartic acid residue in place of the histidine. Revertants, which produced cleaved S and fused cells efficiently at neutral $\mathrm{pH}$, had recovered the connecting peptide RRAHR in most cases, although some revertants had a small, non-charged residue at this position [125].

The coronaviruses of group 1, and SARS-CoV, have an S protein that is not cleaved. Clearly, whatever conformational changes occur following attachment of their S proteins to receptors, the fusion process is not prevented by $\mathrm{S}$ being uncleaved. 
The $\mathrm{S}$ protein of EToV comprises 1,581 amino acids and has a $\mathrm{Mr}$ of about 200,000 when glycosylated. It has a highly basic S1-S2 connecting peptide and occurs as two subunits in virions.

\section{Translation of gene 1: transcriptase/replicase proteins}

Having a positive-sense RNA genome, a coronavirus has no need of proteins within the virion for the RNA replication and transcription process to start. Rather, the input genomic RNA serves as an mRNA for the transcription of gene 1 . This gene accounts for some two-thirds, approximately $20 \mathrm{~kb}$, of the genome. It comprises two very large ORFs, $1 \mathrm{a}$ and $1 \mathrm{~b}$, the second of which is translated following ribosomal frameshifting. The $1 \mathrm{a}$ and $1 \mathrm{~b}$ polyproteins ( $\mathrm{pp} 1 \mathrm{a}$ and $\mathrm{pp} 1 \mathrm{~b}$ ) are co-translationally processed by virusencoded proteases. This topic has been reviewed for toroviruses and arteriviruses in addition to coronaviruses [67].

Gene 1 sequences are available for species within each of the three coronavirus groups plus SARS-CoV. It is within the gene one products that there is the greatest degree of amino acid identity between the coronaviruses, being as high as $70 \%$ in parts of pp1b whilst the identity within much, though not all, of pp1a is not more than $30 \%$. It is pp1a that is also the most variable with respect to size; the greater length of the genome of MHV is largely accounted for by a larger pp1a.

A number of functional domains have been identified within pp1a/b. In pp1a of MHV, HCoV 229E and TGEV there are two papain-like proteases (PLP1 and 2), whereas there is only one, equivalent to PLP2, in IBV and SARS-CoV. The PLPs are involved in the processing of the $\mathrm{N}$ termini of pp1a. Further downstream is a chymotrypsin/picornavirus 3C-like protease (3CLP). This is responsible for all the other cleavage events necessary to generate the gene one products required for RNA replication and transcription [76, 126, 127]. Within pp1b are an RNA-dependent RNA polymerase, a zinc-finger nucleic acid-binding protein and a nucleoside triphosphate-binding helicase. There are also another ten or so proteolytic cleavage products of pp1a and pp1b.

Translation of pp1b involves ribosomal frameshifting. This mechanism has two essential elements: a slippery site followed by an RNA pseudoknot $[128,129]$. At the slippery site (UUUAAAC) the ribosome slips backwards, then proceeds forwards, this time in a -1 frame compared with pp1a.

\section{Transcription}

Coronaviruses have several (five for IBV, seven for TGEV and MHV) 3' co-terminal subgenomic mRNAs, the "nested set" (Fig. 7). It is the unique part of each mRNA, i.e. that which is not contained within the next small- 

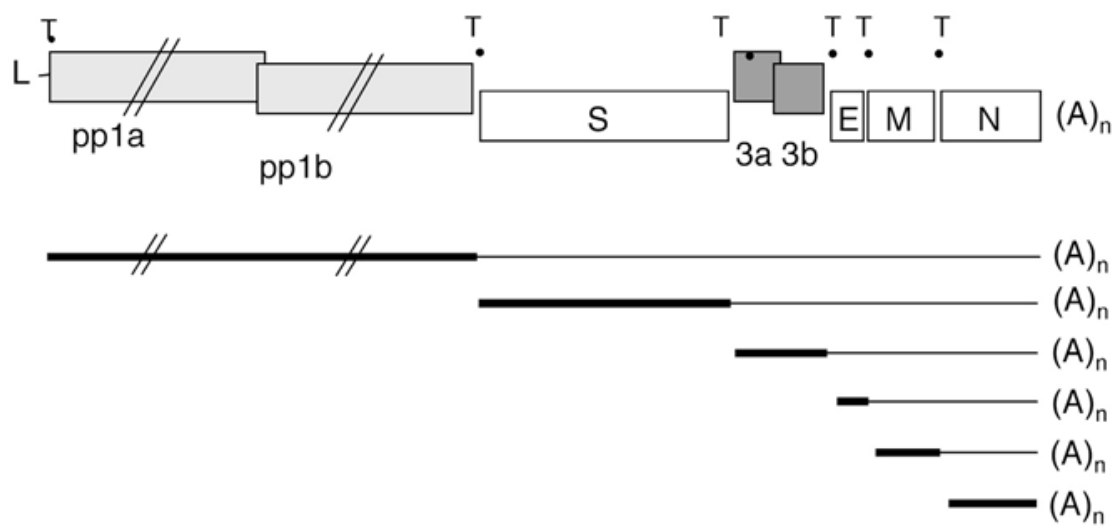

Figure 7. Nested-set arrangement of mRNAs of coronaviruses and toroviruses, illustrated for $\mathrm{HCoV}-229 \mathrm{E}$. The thick horizontal lines indicate the parts of the mRNAs that are translated. The coronaviruses have a transcription-associated sequence (TAS; T) at the beginning of each gene that is associated with the discontinuous transcription process (see Fig. 8). Toroviruses also have sequences equivalent to the TAS of coronaviruses, though discontinuous transcription is not involved in the production of all the subgenomic RNAs (see legend to Fig. 8; [134]). $(\mathrm{A})_{\mathrm{n}}, 3^{\prime}$ poly(A) tail. L, leader sequence.

est mRNA, that is translated. At the 5' end of each gene is a short sequence common to all the genes, or with only minor variations. These were initially called "consensus sequences" and later "intergenic sequences" because, in MHV, they occur in untranslated regions between genes. However, in IBV most of the genes overlap, such that the consensus sequences are within the ORF of the preceding gene. More appropriate names, therefore, are "transcription-associated sequence" (TAS) or "transcription regulating sequence" (TRS) (Fig. 7). In MHV, IBV and SARS-CoV the core TASs are UCUAAAC, CUUAACAA and ACGAAC, with minor variations. At the 5 ' end of each mRNA is a sequence (the leader sequence) of 60-90 nucleotides, depending on the species, derived from the 5' end of the genome (Fig. 7). There is a TAS sequence at the 3' end of the leader. The leader and TAS sequences join in the region of the TAS sequences.

A number of mechanisms have been proposed for the production of the subgenomic mRNAs (reviewed in [31]). The TASs play crucial roles in each model [130-132]. Two models involve discontinuous transcription.

In one model (Fig. 8a) each TAS is an attenuator of the polymerisation process during negative-sense RNA synthesis, the leader sequence then being added to the nascent mRNA to produce a negative-sense subgenomic RNA. A positive-sense mRNA is then transcribed from this.

In the other model (Fig. 8b), a TAS is considered to be more like a promoter. In this model the leader sequence is first transcribed from positivesense genomic RNA, and is then translocated by the polymerase to one or 


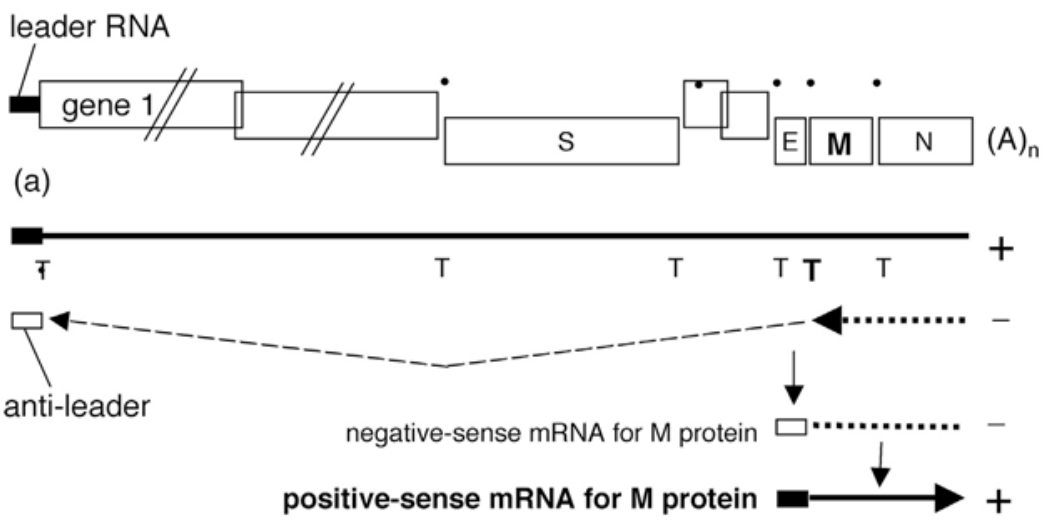

(b)

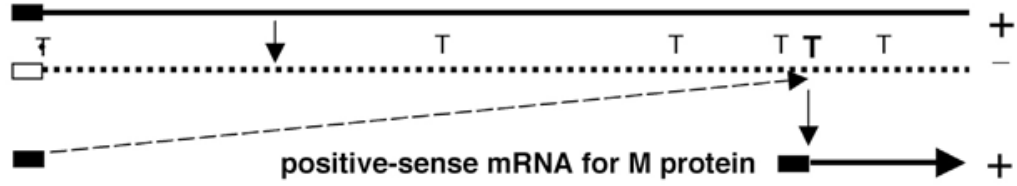

Figure 8. Two models of discontinuous transcription, illustrated for the M gene of HCoV-229E. (a) Discontinuous transcription during negative-strand synthesis, in which the TAS at the beginning of the $\mathrm{M}$ gene attenuates progression of the polymerase, which continues transcription at the 5'-terminal TAS at the end of the leader sequence. The resultant negative-sense mRNA is copied into the actual (plus-sense) subgenomic mRNA. (b) Discontinuous transcription during plus-strand synthesis, in which the template for transcription is the full-length, genome negative-sense RNA. In this model the leader sequence is made first, transcription continuing at one or other of the TAS positions, in this case at the M gene TAS, to generate the M gene subgenomic RNA. Transcription of toroviruses has been studied with EToV. Only the $\mathrm{S}$ gene mRNA of that virus has a leader sequence derived from the 5' terminus of the genome, from which it has been deduced that production of subgenomic mRNAs of toroviruses is a combination of continuous and discontinuous transcription [134].

other of the TAS, after which transcription continues to produce subgenomic positive-sense mRNAs.

The former model is currently favoured, some evidence for it having been produced by investigation of transcription in arteriviruses which, like coronaviruses, are within the order Nidovirales.

The subgenomic mRNAs are not made in equimolar amounts, and the amount of each mRNA does not necessarily decrease in a linear fashion with increasing size of the mRNAs. Sequences adjacent to the TAS sequences affect the efficiency with which a given core TAS operates [133]. 
Transcription in toroviruses has been best studied with EtoV (Berne virus), as this can be grown in cell culture. Unlike coronaviruses and arteriviruses, both in the order Nidovirales, toroviruses were considered not to produce mRNAs by a discontinuous procedure; mRNAs 3, 4 and 5 did not contain a leader sequence. However, mRNA 5 does have a short leader sequence, corresponding to the 5'terminal 18 residues of the genome [134]. Thus EqToV appears to combine discontinuous and non-discontinuous RNA synthesis to produce its subgenomic mRNAs.

\section{Translation of genes downstream from gene 1}

The mRNAs for the HE, S and $\mathrm{M}$ are translated in a cap-dependent manner from mRNAs that are functionally monocistronic; the 5' region, of their respective mRNA, which is absent from the next smaller mRNA, is that which is translated to produce these proteins. This is mostly the case for the $\mathrm{N}$ protein mRNA but in $\mathrm{BCoV}$ and $\mathrm{MHV}$ there is an internal ORF in addition to that encoding the $\mathrm{N}$ protein, i.e. this mRNA is bicistronic. This internal ORF is in a reading frame different from that of the $\mathrm{N}$ protein, encodes a non-essential hydrophobic protein and is translated by a leaky ribosomal scanning mechanism $[135,136]$.

The E protein is translated from a functionally monocistronic mRNA in the case of the group 1 coronaviruses and SARS-CoV but in group 2 and 3 viruses the E proteins is encoded by the second and third ORF, respectively, of bicistronic and tricistronic genes, respectively. Thus the E protein of group 2 and 3 viruses are encoded by ORFs $5 b$ and $3 c$, respectively. The translation of these ORFs commences after internal initiation of translation by ribsomes, not by read-through by ribosomes that had translated the preceding ORF(s) [137, 138]. This internal initiation is controlled by RNA structures formed by the preceding ORFs which act as internal ribosome entry sites $[138,139]$.

\section{Synthesis of the structural proteins}

The $\mathrm{S}$ protein is co-translationally glycosylated with $\mathrm{N}$-linked glycans. Conversion of the high mannose (simple) glycans to complex ones is a slow process, the half-life being one to several hours [27]. The S protein undergoes multiple disulphide linkages to form a more complex structure [140] and oligomerise into a quaternary structure that might be a homodimer or homotrimer [25], homodimer [26, 27] or homotrimer [28]. The S1 and S2 subunits are not held together by disulphide bonds [23]. The $\mathrm{S}$ prepropolypeptide is converted to a propolypeptide by removal of the N-terminal signal peptide. Whether the propolypeptide is cleaved to generate S1 and S2 depends on the virus species and strain and, to some extent, on the 
cell type in which the virus is grown [141]. Essentially the $S$ propolypeptides of the group 2 and $3 \mathrm{CoVs}$ are cleaved at S1-S2 connecting peptides that contain one or more pairs of dibasic residues e.g. RRFRR in many IBV strains $[142,143]$. Cleavage of $S$ occurs after conversion of the glycans from simple to complex [144]. The S propolypeptide of group $1 \mathrm{CoVs}$ and SARS$\mathrm{CoV}$ is not cleaved; they do not have dibasic residues in the region corresponding to the location of the connecting peptide of group 2 and 3 viruses. The $\mathrm{S} 2$ protein of MHV is acylated, probably involving cysteine residues in the C-terminal hydrophobic tail region of S [145].

Like the $\mathrm{S}$ protein, the signal sequence of the HE protein is removed and it has N-linked glycans that are converted to complex ones in the Golgi apparatus. The protein dimerises, the association involving disuphide bonds $[146,147]$.

There are differences amongst the CoVs regarding post-translational processing of the M proteins. All have one or two glycans at the short N-terminal region exposed on the outer surface of the virion (approximately 20 amino acids). In group 2 viruses the glycans are of the O-linked type whereas in group 1 and $3 \mathrm{CoVs}$ they are N-linked [148, 149]. Unlike the M proteins of groups 2 and 3, which have an internal membrane-insertion sequence, those of the TGEV group have an N-terminal membrane-insertion sequence that is absent from the mature $\mathrm{M}$ protein [150], though this signal sequence is not essential $[151,152]$. The M protein of TGEV is sulphated [153].

The E protein of MHV has been reported to be acylated [154].

\section{Replication of genomic RNA}

RNA sequences involved in the control of genomic RNA replication, and transcription, have been mostly studied using coronaviral defective RNAs, as these were considerably smaller $(\leq 9 \mathrm{~kb})$ than genomic RNA [31, 69, 155]. The regulation of coronaviral RNA replication and transcription probably depends on overall RNA confirmation, so the deductions arrived at from experiments with defective RNA must be treated with caution with respect to their applicability to full-size genomic RNA. In the case of MHV, 436 nucleotides at the 3' end of a defective RNA were required for production of positive-strand sequence, whereas only 55 nucleotides were required for negative-strand production. An IBV defective RNA with the 5'-terminal 544 nucleotides, but not as few as 338 nucleotides, and the 3'-terminal 338 nucleotides was replicated [69]. Packaging of the defective IBV RNA into virus particles was poor unless part of gene $1 \mathrm{~b}$ was present, though no specific part of $1 \mathrm{~b}$ was required. A packaging signal was present in the 5'-terminal 649 nucleotides of the TGEV genome [155].

The leader sequence of different strains of MHV varies in length, due to different numbers of repeat copies (two to four copies) of the sequence 
UCUAA [156]. This sequence is part of the core TAS sequence UCUAAAC that occurs at the 3' end of the leader sequence and at the start of each gene. Interestingly, the copy number of this repeat sequence changes during virus passage $[157,158]$. This change in copy number did not occur with $\mathrm{BCoV}$, which only has one UCUAA copy in the leader RNA [159].

\section{Assembly of virus particles}

Electron microscope, protein localisation studies and immunofluoresence analysis have revealed that the major location of coronavirus particle formation is the Golgi complex, although early and late in infection budding can also occur in the endoplasmic reticulum-Golgi intermediate compartment (ERGIC) and rough endoplasmic reticulum, respectively (see Fig. 7 in Salanueva et al. [160]). The expression of combinations of coronavirus proteins from cDNAs to produce, or not, virus-like particles (VLPs) has greatly facilitated our understanding of the process by which virions are assembled. The $\mathrm{E}$ protein is required for the budding process, i.e. for membranes to curve and ultimately bud off to form vesicles. However, it is the M protein that determines the sites at which virus particle formation occurs; it interacts with the $\mathrm{N}$ protein (as part of a ribonucleoprotein complex) and with the S protein (as summarised in the section "What it is to be a coronavirus or torovirus", above). The virus particles are transported through Golgi compartments to secretory vesicles, for subsequent release of virions at the cell surface.

The $\mathrm{M}$ protein accumulates in the Golgi complex in homomultimeric complexes $[48,49,161]$. When produced on its own, e.g. by expression from cDNAs or virus vectors, the S protein migrates to the cell surface. Indeed, some does so during infection. However, these molecules are then lost to the process of virus particle formation. Rather, the $\mathrm{S}$ molecules that become part of virions are retained in the Golgi complex by interaction with the $\mathrm{M}$ protein, via $\mathrm{C}$-terminal regions of the $\mathrm{S}$ protein [50-52]. Virus-like particles could be formed experimentally when both $\mathrm{E}$ and $\mathrm{M}$ were expressed together but not if either of them was absent. Neither $\mathrm{N}$ nor $\mathrm{S}$ proteins were required to form these virus-like particles [39, 40]. When the $\mathrm{N}$ protein is present, associated with the genomic RNA to form the RNP, this structure associates with the the $\mathrm{C}$-terminal half of the $\mathrm{M}$ protein) to form an icosahedral core structure $[47,162,163]$.

Although the $\mathrm{M}$ protein is central to the virus assembly process, the $\mathrm{E}$ protein, which is also an integral membrane protein, is required to induce membrane curvature that culminates in budding. The effect of the E protein on membranes has been illustrated by Fischer et al. [164] who produced deformed MHV particles when certain parts of the E protein had been mutated. It is the lumenal part of $\mathrm{E}$, i.e. on the inside of the virion, that tar- 
gets the protein to the Golgi complex [165]. The last six residues, RDKLYS, of the C-terminus of the E protein of IBV were responsible for temporal retention of $\mathrm{E}$ in the pre-Golgi compartment [166].

Expression of $\mathrm{E}$ and $\mathrm{M}$ together resulted in the production of VLPs $[39,40,167]$. However, expression of $\mathrm{E}$ protein alone is able to produce, showing that the E protein alone can induce budding [55, 168]. However, the $\mathrm{E}$ protein is not absolutely essential for the production of virus particles. Thus mutant MHVs have been made that lack the E protein gene but which still replicate, albeit to a titre of $10^{4}$-fold less than wild type virus [169]. Notwithstanding, it can be said that the E protein greatly enhances virion envelope formation. Kuo and Masters [170] have suggested that $\mathrm{E}$ induces membrane curvature whilst $\mathrm{M}$ drives the remainder of the virion production process. Lim and Liu [166], using IBV, have expressed various deletions of $\mathrm{E}$ and looked for interaction of $\mathrm{E}$ and $\mathrm{M}$ by immunoprecipitation. The results suggested that the sequence immediately downstream from the putative membrane-spanning region of $\mathrm{E}$ interacted with $\mathrm{M}$.

Electron microscope analysis of TGEV-infected cells has revealed two types of virion-related particles $[160,171]$. The larger of the two had an electron dense internal periphery and a clear central area. These particles were located at perinuclear regions. Smaller particles were seen to accumulate in secretory vesicles. These smaller particles resembled the virus particles that were released from cells, i.e. they had compact internal cores with polygonal contours. It was concluded that the larger particles were the precursors of the smaller ones, and that the changes occurred during transport through the Golgi complex.

\section{Recombination}

Recombination is a feature of coronavirus replication. Chimaeric progeny arise probably by a copy-choice mechanism, i.e. the polymerase periodically falls off the viral RNA template that it is copying and may re-attach on the same or another viral template in the same cell. This probably occurs during replication of a single strain of a coronavirus, which would not usually be apparent. In this circumstance recombination may be a repair mechanism [172]. If a cell is infected by two strains of a given species of coronavirus, then progeny with sequence(s) derived from both parents may result. This phenomenon was discovered with two temperature-sensitive mutants of MHV [173] and has been reviewed [31]. It is sometimes stated that coronavirus recombination occurs at high frequency. This high frequency may only be true of MHV in experimental circumstances [174]. Notwithstanding, recombination is a feature of the evolution of coronaviruses. Recombination between strains of IBV has been demonstrated experimentally [175] whilst sequencing of many field strains has provided 
convincing evidence that many, possibly all, IBV strains are recombinants between different IBV strains [176-180].

Two forms of FCoV are known, types I and II. FCoV type II is believed to be a recombinant of FCoV type I and CECoV [181], both group 1 CoVs.

In addition to homologous recombination events, i.e. between strains of a given species of coronavirus, or even between different species of coronavirus, non-homologous recombination events have occurred. Thus the HE gene of the group 2 coronaviruses, and the toroviruses, is similar to part of the $\mathrm{HEF}$ gene of influenza $C$ virus, a negative-strand virus. The $\mathrm{HE}$ gene of coronaviruses and toroviruses may have been derived by independent recombination between a coronavirus/torovirus and influenza $C$ virus. Comparison between genomic structures of coronavirus and torovirus also suggests that several recombination events may have been involved in rearranging the order of several genes during the evolution of these viruses [182]. For example, the C terminus of ppla of EToV has 31 to $36 \%$ amino acid identity with the N-terminal 190 amino acids of the 30-32 kDa nonstructural 2A protein of coronaviruses.

Evidence for recombination between species of the Torovirus genus has been forthcoming from sequence analyses of BToV and porcine torovirus (PToV) isolates. For example, all of the newly characterized BToV variants had a 3' end of the HE gene, and the downstream $\mathrm{N}$ gene and 3'UTR that more closely resembled those of PToV than older BToVs [66]. Chimaeric $\mathrm{HE}$ genes in some PToV and BToVs suggested not only recombination but also the existence of other toroviruses.

There are constraints on the production of viable chimaeric coronaviruses by recombination, especially between different coronavirus species. For example, the structural proteins are not mutually independent of each other. As described above, the $\mathrm{M}$ protein interacts with the C-terminal part of S (the transmembrane domain and the cytoplasmic tail), with the $\mathrm{N}$ protein and probably with the $\mathrm{E}$ protein. Hence viable virus would only ensue from recombination of different coronaviruses within the structural protein gene region if these interactions were not compromised.

\section{Variation in the spike glycoprotein}

Within a coronavirus species it is the $\mathrm{S}$ protein that generally exhibits the greatest sequence variation. Most differences occur within the amino-terminal part of the molecule, equivalent to the N-terminal S1 glycopolypeptide in the case of those coronaviruses in which the $\mathrm{S}$ protein is cleaved into two polypeptides. There appear to be more constraints on the sequence of the S2 polypeptide, this polypeptide being involved in anchoring the protein in the membrane, forming the coiled-coil multimeric mature S protein and activating membrane fusion. By contrast, the function of the S1 subunit would seem to be limited to providing a receptor-binding domain. Provided 
that is intact, the sequence, and structure, of much of the remainder of S1 would seem not to be as crucial as for S2.

This is most vividly illustrated in the case of IBV, which exists as scores, maybe hundreds, of serotypes. Most IBV serotypes differ from each other by 20 to $25 \%$ of $\mathrm{S} 1$ amino acids $[183,184]$, the S2 polypeptides differing by less than half that amount (reviewed in [29]). However, some serotypes differ by $50 \%$ of S1 amino acids [185-187]. (Differences between the other IBV proteins are in the range of $10 \%$, rarely exceeding $15 \%[188,189]$. The differences between the S1 proteins undoubtedly have a selective advantage; generally speaking, the immunity induced by inoculation with one serotype protects poorly against infection with heterologous serotypes (reviewed by Cavanagh [80]). Differences of as few as 2 to 3\% of S1 amino acid residues can result in a change in serotype, defined as lack of crossneutralization using convalescent sera [190-192]. These few differences may contribute to diminished cross-protection in challenge experiments in chickens [193, 228].

Investigation of monoclonal antibody-resistant mutants revealed that many of the amino acids involved in the formation of $\mathrm{VN}$ epitopes are located within the first and third quarters of the linear S1 polypeptide [194196]. Sequence analysis of naturally occurring variants that are genetically very similar ( $>95 \%$ amino acid identity in S1) has shown that most of the differences are within these two regions $[185,190]$. Thus these parts of S1 are very tolerant of amino acid changes, changes that probably confer a selective advantage.

Amongst group 2 coronaviruses sequence variation is also greater in S1 than S2, a C-terminal region of S1 being hypervariable (Fig. 9). Indeed, this region is deleted in variants of $\mathrm{MHV}$. Deletions in the N-terminal part of S1 have not been observed with group 2 viruses. This correlates with the finding that the receptor-binding domain of $\mathrm{MHV}$ is within the N-terminal 330 residues (Fig. 5; [197]).

In group 1, it is the $\mathrm{N}$-terminal 300 or so residues of $\mathrm{S}$ that are most variable. From position 300 to the end of the molecule (at approximately residue number 1450) TGEV, CECoV type II and FCoV type II have $\geq 94 \%$ amino acid identity (80-90\% throughout the whole $\mathrm{S}$ protein). Within the first 300 residues this falls to $\sim 85 \%$ between FCoV type II and CECoV type II, and to $~ 30 \%$ between FCoV type II and TGEV. Moreover, the nonenteropathogenic variant of TGEV, called porcine respiratory coronavirus, has 225 of the first 300 amino acids deleted [198] (for additional references see reviews $[29,199,200])$. This extreme variation at the $\mathrm{N}$-terminal part of $\mathrm{S}$ of group 2 viruses correlates with the receptor-binding domain being further down the molecule (Fig. 5; [96]).

The feline and canine coronaviruses of group 1 are not homogeneous. Thus, although the type II FCoVs and type II CECoVs have $~ 90 \%$ identity in the whole $\mathrm{S}$ protein, the type I FCoVs and type I CECoVs have only $\sim 45 \%$ identity with the type II viruses. 


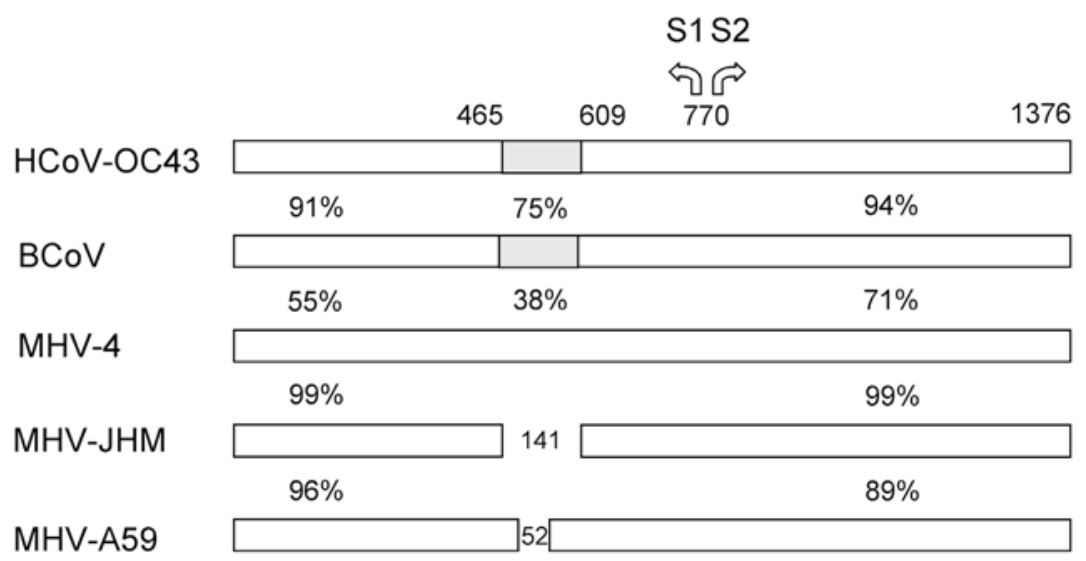

Figure 9. Amino acid identity between three regions of the $\mathrm{S}$ proteins of three species of group 2 coronavirus, and between three strains of MHV. Identity between species is greatest in S2. In the C-terminal part of S1 is a hypervariable region (in grey). This is not only the region of least identity between species; it is also a region which has been deleted from some strains of MHV. The amino acid identity between the S protein of $\mathrm{BCoV}$ and another isolate of $\mathrm{HCoV}-\mathrm{OC} 43$ was $>98 \%$ [202]).

The full-length S proteins of HCoV-229E and PEDV have only 45\% amino acid identity with each other and with the other members of group 1.

\section{Host range of coronaviruses and toroviruses}

Although coronaviruses have been described as being fastidious with regard to their hosts, this is true in vitro but not in vivo. Thus it has been very difficult to obtain cell cultures to grow some coronaviruses. Whereas the HCoV-229E and related strains can be isolated in human embryonic lung fibroblasts, such as W138 and MRC5 cells, HCoV-OC43-related strains usually cannot be grown in cell cultures, at least on initial isolation, and for these strains isolation has been performed in organ cultures of human embryonic tissues (reviewed by Myint, [201]). TCoV can only be grown in embryonated turkey eggs, and to a lesser extent in chicken embros. HToVs have not been grown in culture. However, the host range of coronaviruses, and probably toroviruses [66], is greater in vivo.

An $\mathrm{HCoV}$ isolate, of the OC43 genotype, had $>99 \%$ amino acid identity in the $\mathrm{S}$ and $\mathrm{HE}$ proteins with the corresponding proteins of $\mathrm{BCoV}$ [202]. A recently discovered respiratory canine coronavirus is a group 2 coronavirus [203], the S protein of which had $96 \%$ and $95 \%$ amino acid identity with that of $\mathrm{BCoV}$ and $\mathrm{HCoV}-\mathrm{OC} 43$, respectively. Cross-infection by these viruses has not been studied but a broad host range for them is a possibility. Turkeys are naturally infected with a coronavirus that is genet- 
ically very similar to IBV i.e. the same group 3 genome organisation and most proteins with $>85 \%$ amino acid identity [188]. Notwithstanding, turkeys have been successfully infected with $\mathrm{BCoV}$, a group 2 virus, leading to diarrhoea [204].

Group 1 coronaviruses include TGEV, FCoV and CECoV. CECoV experimentally applied orally to pigs replicated in them, inducing antibodies though not causing disease [205]. When hysterectomy-derived pigs were infected orally by these three viruses, virulent FCoV type I caused villous atrophy in the jejunum and ileum, resulting in clinical signs typical of a virulent TGEV infection, and death of 3/12 pigs. Cell culture-adapted FCoV and virulent $\mathrm{CECoV}$ produced less severe lesions and no mortality. Replication of these coronaviruses was confirmed by immunofluorescence.

Given the above, it is not surprising that viruses with $>99 \%$ nucleotide identity with SARS coronavirus from humans were identified in nearby animals, namely in the Himalayan palm civet cat and racoon dog during the SARS epidemic in China. Experiments have subsequently shown that human isolates of SARS-CoV can replicate, and cause disease, in cynomolgus macaques (Macaca fascicularis [206]), in ferrets (Mustela furo) and domestic cats (Felis domesticus [207]). Several cats and a dog were found to be positive for SARS-CoV in the Amoy Gardens outbreak in Hong Kong.

Most of the known coronaviruses (Tab. 1) are known because they are pathogens of economic importance (e.g. cattle, pigs) or of social importance (cats, dogs, humans), and take their name from their hosts. The SARS epidemic in humans, and the rediscovery of what we already knew about other, long-known coronaviruses (outlined above), tells us that the host range of coronaviruses is much wider than was previously supposed.

\section{Tropisms of coronaviruses}

The naming of coronaviruses, like many other viruses, has often been based on the site at which pathology is manifest in a particular host species, e.g. avian infectious bronchitis coronavirus, Murine hepatitis virus. In some cases names have been simplified in recent years, e.g. bovine enteric coronavirus to bovine coronavirus, feline infectious peritonitis virus to feline coronavirus. It has been mooted that murine hepatitis coronavirus should be renamed to simply murine coronavirus. These changes reflect that within a host species a coronavirus replicates in many more tissues than its name would imply. This is well illustrated by IBV, which replicates at a myriad of epithelial surfaces (Fig. 10; reviewed in [80, 208, 209]. TGEV not only replicates at some enteric surfaces, as its name implies, but also in kidneys and lung (reviewed by Garwes [200]). MHV initially replicates in the gut but may then be disseminated to other organs e.g. liver and central nervous system (CNS), where it might cause pathology [210]. FCoV usually causes no more than an enteritis but in some cases, for reasons still not fully under- 


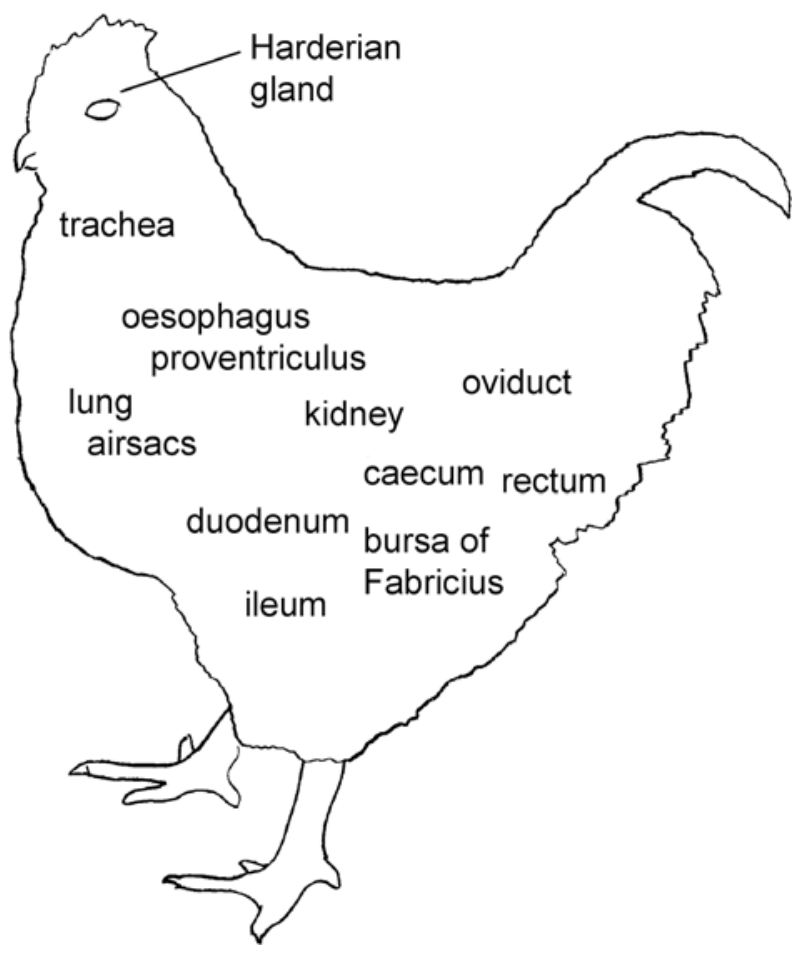

Figure 10. Tissues of the domestic fowl that become productively infected with IBV after inoculation of the nose and by eye-drop. The Harderian gland is a small lymphatic organ behind the eye. The proventriculus is a cranial glandular compartment of the stomach, adjacent to the gizzard, which is the caudal muscular compartment.

stood (but perhaps including the nature of the immune response of the host), it causes infectious peritonitis (actually, a vasculitis; reviewed by de Groot and Horzinek [211], and Addie and colleagues [212, 213]). HEV of pigs initially replicates in the respiratory tract and pharyngeal tonsils, then spreads via the peripheral nervous system to the CNS [200].

I have already hinted that strains of a given coronavirus species differ with respect to tropism. Although most strains of IBV replicate in the chicken kidney, only a few are intrinsically nephropathogenic (able to cause kidney-related mortality in experimentally infected chickens), causing up to 44\% mortality [214-217]. Recently Yu et al. [218] have studied the pathogenesis of three isolates of IBV that caused proventriculitis, mortality being age-dependent (75-100\% in two-week-old birds; 0-25\% in 16-week-old chickens).

MHV strains vary with respect to not only whether they cause pathology in the CNS but also in the nature of the pathology e.g. acute or chronic 
demyelination [210], reviewed by Dales and Anderson [219], Stohlman and Hinton, [220] and Matthews et al. [221]. A number of enveloped and nonenveloped, RNA and DNA viruses have been associated with demyelination in humans and rodents, including coronaviruses [220]. Several studies [222,223], though not all [224], have resulted in the detection of coronavirus RNA in brain tissue of multiple sclerosis patients. Arbour et al. [222] hypothesized that HCoV RNA might sometimes lead to a low level of viral protein synthesis that could be involved in the stimulation of immune responses within the CNS, exacerbating the effect of coronaviral infection in MS patients. Experiments have shown that both $\mathrm{HCoV}-\mathrm{OC} 43$ and HCoV-229E can establish acute infections in many human neural cell lines: astrocytoma, neuroblastoma, neuroglioma, oligodendrocyte and microglial cell lines [225]. Persistent infections were established in some of the lines.

Some strains of TGEV do not cause enteritis. Most well known are those that have been called porcine respiratory coronavirus. As would be expected from this name, such variants replicate, as do the classical enteric strains of TGEV, in the respiratory tract, though usually asymptomatically, but replicate to only low levels in the enteric tract (reviewed by Garwes, [200] and Enjuanes and van der Zeijst [199]). The non-enteric strains have a large deletion in the $\mathrm{S}$ protein gene, as explained above.

These are just some of the examples of the different tropisms manifest by variants of a given coronavirus species. The pantropism of IBV might be the case for SARS coronavirus, as the latter has not only been associated with pneumonia but also with diarrhoea (though it remains to be demonstrated if the SARS virus is replicating in enteric tissues [227]). A point of difference is that whereas SARS CoV is associated with severe clinical signs in both the respiratory and enteric tracts, IBV is usually limited to disease in the respiratory tract (though the nephropathogenic and proventriculopathogenic strains of IBV are exceptions). Indeed, if it is demonstrated that SARS-CoV was directly responsible for the pathology in both respiratory tract and gut, it will be one of the few cases in which a given strain of a coronavirus has caused serious pathology in both regions.

Before the appearance of SARS there were reports describing coronavirus-like viruses isolated from faecal specimens from humans [33]. Some of these viruses were isolated from infants with necrotizing enterocolitis, patients with non-bacterial gastroenteritis and from homosexual men with diarrhoea who were symptomatic and seropositive for human immunodeficiency virus. Some isolates were shown to be serologically related to $\mathrm{HCoV}$ OC43. The discovery that a protein found in enterocytes functions as a receptor for $\mathrm{HCoV}-229 \mathrm{E}$ strengthens the likelihood that coronaviruses might replicate in the human alimentary tract.

Evidence has increased that toroviruses are associated with gastroenteritis in humans. In a case-control study of children, an antigen capture ELISA revealed torovirus in stools from 27\% (9/33) of children with acute diarrhoea, 27\% (11/41) with persistent diarrhoea and none in controls [21]. 
In another childhood study, electron microscopy revealed a torovirus incidence of $35 \%$ (72/206) and $15 \%$ in gastroenteritis cases and controls, respectively [22].

\section{Determinants of pathogenicity}

There are doubtless many positions in the genomes of coronaviruses in which mutations can lead to changes in pathogenicity. For example, when we replaced the S protein gene of an attenuated strain of IBV with that from a pathogenic strain, it remained non-pathogenic [228], although its tropism in vitro had been changed [229]. Notwithstanding, the S protein can be a major determinant of pathogenicity. Ballesteros et al. [174] produced recombinants from enteropathogenic and non-enteropathogenic strains of TGEV which had extremely similar genome sequences. Some of the recombinants were non-enteropathogenic, the authors concluding that only one or two amino acid differences in the S protein were associated with the nonenteropathogenic phenotype. The authors produced further support for the role of the $\mathrm{S}$ protein in enteropathogenicity by producing recombinant TGEV by targeted recombination [230]. They further suggested that two domains on the $\mathrm{S}$ protein might be involved in attachment to enteric cells, one for binding to porcine aminopeptidase $\mathrm{N}$. This receptor is present in lung tissue as well as in enteric tissue; binding to this does not account for the different tropisms. The other domain might be involved in the binding to a coreceptor, not defined, essential for the enteric tropism; differences in this domain affected the tropism of TGEV. The situation might be even more complex, as there is also evidence for the involvement of cell surface sialoglycoproteins as receptors for TGEV [101, 102].

The $\mathrm{S}$ protein determines the nature of the neurovirulence of MHV strains. This had been suspected from early sequencing studies (Fig. 10) and has been confirmed by sequencing of mutants arising during replication in persistently infected glial cells [231], and by mutants generated by targeted recombination [232-234]. For example, when the $\mathrm{S}$ protein gene of a demyelinating strain of MHV (A59) was replaced with that of a nondemyelinating strain (MHV-2), the resultant recombinant was nondemyelinating [232]. The A59 strain is also hepatotropic, whereas the MHV4 strain has only minimal effect on the liver. Spike-swapping by targeted recombination showed that the hepatotropism was determined by the $\mathrm{S}$ protein [235].

Feline cells in vitro, which are normally refractory to infection by MHV, were productively infected by recombinant $\mathrm{MHV}$ in which the $\mathrm{S}$ protein gene has been replaced by that from FCoV [3]. In other words, MHV was able to replicate well in feline cells provided that it had an S protein capable of initiating infection. Genes other than S affect pathogenicity. The nonstructural proteins of coronaviruses, not least SARS-CoV, are attracting 
attention. Deletion of all the non-structural protein genes of MHV produced virus that replicated in mice but which, unlike the wild-type virus, was non-lethal [10]. Inactivation (whether by deletion or other modification) of individual non-structural protein genes does not necessarily result in reduced pathogenicity. FcoV, unable to make the ORF $7 \mathrm{~b}$ protein, was still lethal for cats [1]. Removal of gene 3 of TGEV did not diminish its enteropathogenicity [75]. IBV, unable to make non-structural proteins 3a and $3 \mathrm{~b}$ or $5 \mathrm{a}$ and $5 \mathrm{~b}$ (our unpublished observations), remained lethal for chick embryos.

\section{Persistent infections, asymptomatic shedding}

A feature of at least some coronaviruses is that they establish persistent infections not only in vitro but also in vivo. Chicks that had been experimentally infected with IBV at one day of age re-excreted virus asymptomatically at around 19 weeks of age [236]. It is suspected that the stressor of the start of egg production caused the release of the virus. Similar observations have been made more recently [237]. Approximately $10 \%$ of cats that had been naturally infected with FCoV became asymptomatic carriers, excreting virus for over one year $[212,213]$. Others excreted virus for periods of several months. Long-term infections of $\mathrm{MHV}$ in mice and rats have been known for a long time, associated with neuropathogenesis.

\section{Vaccines}

Vaccination against coronavirus infections has been undertaken with respect to $\mathrm{IBV}, \mathrm{TGEV}, \mathrm{CECoV}, \mathrm{FCoV}$ and $\mathrm{BCoV}$. Of these, vaccination has been most widely, and arguably most successfully, practised in respect of IBV, for over 50 years [80].

Meat-type chicks (broilers) are usually vaccinated on the day of hatch with live attenuated vaccinal strains applied by spray. Protection of the respiratory tract following a single live attenuated virus vaccination has been found to be short-lived, the number of protected chickens declining after 6 weeks [238, 239]. As explained above, IBV exists as many serotypes, crossprotection between them often being poor. Consequently IBV vaccines have been developed with several serotypes. Vaccination with live attenuated virus is effective not only against respiratory disease but also kidney involement [217].

Inactivated oil-emulsion IBV vaccines were developed during the 1960s and 1970s. The objective was to make a vaccine that would give longlasting immunity to the hen bird, to protect against drops in egg production. When used without prior priming with live IBV vaccine, killed IBV vaccines produced immunity in too few chickens, even when multiple 
doses of up to $200 \mu \mathrm{g}$ of purified, inactivated virus were used [240-242]. The approach commonly used in the poultry industry today is to vaccinate young females two or more times with live vaccine, followed by one dose of inactivated vaccine as the birds come into lay. The live vaccines serve to give protection to the young bird and to prime the immune response to the inactivated vaccine.

Passive administration of convalescent IBV serum to chickens protected against intravenous application of a strain known to produce nephritis [243]. This passive application of immune serum did not protect against respiratory infection, although onset was delayed and was of shorter duration.

The efficacy of vaccination with live vaccine varies amongst inbred lines of chickens i.e. genetic differences between individuals affects the efficacy of the immune response [244-247].

Efforts to make effective vaccines against infectious peritonitis caused by FCoV have been ongoing for many years. A phenomenon that has militated against their widespread application has been that of antibodydependent enhancement of disease. That is, antibodies induced by a first infection or vaccination may enhance the disease caused by a subsequent infection. Infection of cats by FCoV usually results in an infection confined largely to the digestive tract. In some cases the virus disseminates to other organs, leading to fatal infectious peritonitis. This dissemination is facilitated by macrophages. It is believed that uptake of FCoV by macrophages is enhanced when the virus has immunoglobulins, induced by a prior infection or vaccination, on its surface; the Fc moiety of the immunoglobulin attaches the virus-antibody complex to the surface of the macrophage (reviewd in [211]; see also [212, 213]).

Vaccines have not been developed against human coronaviruses. Immunity following natural infection is short-lived. Re-infection of individuals with the same $\mathrm{HCoV}$ serotype often occurs within four months of the first infection, suggesting that homologous $\mathrm{HCoV}$ antibodies are protective for about four months [11].

\section{Proteins involved in the induction of protective immunity}

There is no doubt that the $\mathrm{S}$ protein, when inoculated on its own, can induce protective immunity. The proportion of animals being protected may be dependent on the manner by which the $\mathrm{S}$ protein is presented to the host. There is also evidence that the $\mathrm{N}$ protein can prime protective immune responses, and a report that the $\mathrm{N}$ protein of IBV on its own induced protective immunity.

As would be expected from its global economic importance, there have been several studies on the induction of immunity by IBV (reviewed by Cavanagh, [80]). The S1 subunit induces immunity. S1 produced in a number 
of ways has been used as an immunogen: by removal from virus by urea (in which event the S1 was no longer multimeric [240]); by removal from virus using non-ionic detergent, followed by affinity chromatography using monoclonal antibodies; by expression in Spodoptera frugiperda cells from a recombinant Autographa californica baculovirus [242]. Immunisation with these various $\mathrm{S} 1$ preparations induced protective immunity against respiratory and kidney disease in a proportion of chickens, up to about $80 \%$ after four inoculations of S1. More strikingly, greater protection was achieved following a single oral application of a non-pathogenic fowl adenovirus expressing S1 [248]. Protection, assessed by non-reisolation of challenge virus, was obtained in $90 \%$ and $100 \%$ of 10 to 13 chickens in two experiments.

Similarly, expression of the MHV S protein from an adenovirus vector protected mice from lethal challenge [249]. Earlier Daniel and Talbot (1990) [267] had shown that immunisation of mice with S recovered from purified virus protected against lethal challenge with MHV.

The first study of the role of the IBV N protein in immunity was by Boots et al. [250]. Although immunisation with $\mathrm{N}$ alone did not induce protective immunity, subsequent immunisation with inactivated IBV resulted in greater protection than when the inactivated vaccine alone was administered. The authors concluded that immunisation with the $\mathrm{N}$ protein had primed protective immune responses by activation of cytotoxic or helper $\mathrm{T}$ cell responses.

More strikingly, two intramuscular immunisations of chickens with a plasmid expressing the $\mathrm{N}$ protein, or a fragment of the $\mathrm{N}$ protein, induced immune responses that protected the birds from infection by IBV, as evidenced by marked reduction in replication of the challenge virus [251]. A fragment of the $\mathrm{N}$ protein comprising the $\mathrm{C}$-terminal 120 amino acid residues contained a major $\mathrm{T}$ cell epitope, and was sufficient to induce protection. The immunisation induced cytotoxic $\mathrm{T}$ lymphocytes that were deemed to be responsible for the protection. CTL activity was major histocompatibility complex restricted, and lysis was mediated by $\mathrm{CD} 8^{+} \mathrm{CD} 4^{-}$ cells [252]. Adoptive transfer of IBV infection-induced $\alpha \beta$ T cells bearing CD8 antigen protected chicks from challenge infection [253,254]. An early and strong T-helper cell response specific for the $\mathrm{N}$ protein of MHV has been reported [255]. When mice received $\mathrm{N}$ protein-specific $\mathrm{CD} 4^{+} \mathrm{T}$ cells by adoptive transfer, they were protected against an otherwise lethal challenge with MHV. Further studies have shown the presence of helper and cytotoxic $\mathrm{T}$ cell epitopes in the C-terminal part of the MHV $\mathrm{N}$ protein [256-259].

Passive administration of monoclonal antibodies against the MHV S and, separately, N, proteins, protected mice against lethal challenge with MHV [260]. Similarly, expression of the MHV S and N proteins, separately, from adenovirus vectors protected mice from lethal challenge [249]. Greater protection was obtained when mice had been immunised simultaneously with both of the adenovirus recombinants. 


\section{Final comments}

During 2002 PubMed abstracted approximately 130 papers featuring coronaviruses. This rose to approximately 510 in 2003, an increase of almost four-fold. This rise was, of course, a consequence of SARS. The speed with which scientists identified and characterised SARS CoV, and many aspects of its biology, was astounding. The remainder of this book reviews what was revealed in such a short time.

\section{Acknowledgements}

The author is supported by the Department for the Environment, Food and Rural Affairs, and the Biotechnology and Biological Sciences Research Council, UK.

\section{References}

1 Haijema BJ, Volders H, Rottier PJ (2003) Switching species tropism: an effective way to manipulate the feline coronavirus genome. J Virol 77: $4528-4538$

2 Koetzner CA, Parker MM, Ricard CS, Sturman LS, Masters PS (1992) Repair and mutagenesis of the genome of a deletion mutant of the coronavirus mouse hepatitis virus by targeted RNA recombination. $J$ Virol 66: $1841-1848$

3 Kuo L, Godeke GJ, Raamsman MJ, Masters PS, Rottier PJ (2000) Retargeting of coronavirus by substitution of the spike glycoprotein ectodomain: crossing the host cell species barrier. J Virol 74: 1393-1406

4 Masters PS (1999) Reverse genetics of the largest RNA viruses. Adv Virus Res 53: $245-264$

5 Thiel V, Herold J, Schelle B, Siddell SG (2001) Infectious RNA transcribed in vitro from a cDNA copy of the human coronavirus genome cloned in vaccinia virus. J Gen Virol 82: 1273-1281

6 Almazán F, González JM, Pénzes Z, Izeta A, Calvo E, Plana-Durán J, Enjuanes L (2000) Engineering the largest RNA virus genome as an infectious bacterial artificial chromosome. Proc Nat Acad Sci USA 97: 5516-5521

7 Yount B, Curtis KM, Baric RS (2000) Strategy for systematic assembly of large RNA and DNA genomes: transmissible gastroenteritis virus model. J Virol 74: 10600-10611

8 Yount B, Denison MR, Weiss SR, Baric RS (2002) Systematic Assembly of a Full-Length Infectious cDNA of Mouse Hepatitis Virus Strain A59. J Virol 76: 11065-11078

9 Yount B, Curtis KM, Fritz EA, Hensley LE, Jahrling PB, Prentice E, Denison MR, Geisbert TW, Baric RS (2003) Reverse genetics with a full-length infectious cDNA of severe acute respiratory syndrome coronavirus. Proc Natl Acad Sci USA 100: 12995-13000 
10 de Haan CA, Masters PS, Shen X, Weiss S, Rottier PJ (2002) The group-specific murine coronavirus genes are not essential, but their deletion, by reverse genetics, is attenuating in the natural host. Virology 296: 177-189

11 Cavanagh D (2004) Coronaviruses and toroviruses. In: AJ Zuckerman JE Banatvala, PD Griffiths, JR Pattison, BD Schoub (eds): Principles and Practice of Clinical Virology, 5th ed., John Wiley \& Sons Ltd, Chichester, 379-397

12 Makela MJ, Puhakka T, Ruuskanen O, Leinonen M, Saikku P, Kimpimaki M, Blomqvist S, Hyypia T, Arstila P (1998) Viruses and bacteria in the etiology of the common cold. J Clin Microbiol 36: 539-542

13 Pitkaranta A, Hayden FG (1998) What's new with common colds? Pathogenesis and diagnosis. Infections Med 15: 50-57

14 Pene F, Merlat A, Vabret A, Rozenberg F, Buzyn A, Dreyfus F, Cariou A, Freymuth F, Lebon P (2003) Coronavirus 229E-related pneumonia in immunocompromised patients. Clin Infect Dis 37: 929-932

15 McKean MC, Leech M, Lambert PC, Hewitt C, Myint S, Silverman M (2001) A model of viral wheeze in nonasthmatic adults: symptoms and physiology. Eur Respir J 18: 23-32

16 Gagneur A, Legrand MC, Picard B, Baron R, Talbot PJ, de Parscau L, Sizun J (2002) Nosocomial infections due to human coronaviruses in the newborn. Arch Pediatr 9: 61-69

17 Falsey AR, Walsh EE, Hayden FG (2002) Rhinovirus and coronavirus infection-associated hospitalizations among older adults. $J$ Infect Dis 185: 1338-1341

18 Freymuth F, Vabret A, Brouard J, Toutain F, Verdon R, Petitjean J, Gouarin S, Duhamel JF, Guillois B (1999) Detection of viral, Chlamydia pneumoniae and Mycoplasma pneumoniae infections in exacerbations of asthma in children. $J$ Clin Virol 13: 131-139

19 Atmar RL, Guy E, Guntupalli KK, Zimmerman JL, Bandi VD, Baxter BD, Greenberg SB (1998) Respiratory tract viral infections in inner-city asthmatic adults. Arch Intern Med 158: 2453-2459

20 van Benten IJ, KleinJan A, Neijens HJ, Osterhaus AD, Fokkens WJ (2001) Prolonged nasal eosinophilia in allergic patients after common cold. Allergy 56: 949-956

21 Koopmans MP, Goosen ES, Lima AA, McAuliffe IT, Nataro JP, Barrett LJ, Glass RI, Guerrant RL (1997) Association of torovirus with acute and persistent diarrhea in children. Pediatr Infect Dis J 16: 504-507

22 Jamieson FB, Wang EE, Bain C, Good J, Duckmanton L, Petric M (1998) Human torovirus: a new nosocomial gastrointestinal pathogen. $J$ Infect Dis 178: $1263-1269$

23 Cavanagh D, Davis PJ (1986) Coronavirus IBV: Removal of spike glycopeptide S1 by urea abolishes infectivity and haemagglutination but not attachment to cells. J Gen Virol 67: 1443-1448

24 Stern DF, Burgess L, Sefton BM (1982) Structural analysis of virion proteins of the avian coronavirus infectious bronchitis virus. J Virol 42: 208-219

25 Cavanagh D (1983) Coronavirus IBV: further evidence that the surface projections are associated with two glycopolypeptides. J Gen Virol 64: 1787-1791 
26 Lewicki DN, Gallagher TM (2002) Quaternary structure of coronavirus spikes in complex with CEACAM cellular receptors. J Biol Chem

27 Vennema H, Heijnens L, Zijderveld A, Horzinek MC, Spaan WJM (1990) Intracellular transport of recombinant coronavirus spike proteins: implications for virus assembly. J Gen Virol 64: 339-346

28 Delmas B, Laude H (1990) Assembly of coronavirus spike protein into trimers and its role in epitope expression. $J$ Virol 64: 5367-5375

29 Cavanagh D (1995) The coronavirus surface glycoprotein. In: Siddell SG (ed): The Coronaviridae. Plenum Press, New York and London, 73-113

30 Gallagher TM, Buchmeier MJ (2001) Coronavirus spike proteins in viral entry and pathogenesis. Virology 279: 371-374

31 Lai MMC, Cavanagh D (1997) The molecular biology of coronaviruses. $A d v$ Virus Res 48: 1-100

32 Cornelissen LA, Wierda CM, van der Meer FJ, Herrewegh AA, Horzinek MC, Egberink HF, de Groot RJ (1997) Hemagglutinin-esterase, a novel structural protein of torovirus. $J$ Virol 71: 5277-5286

33 Duckmanton L, Luan B, Devenish J, Tellier R, Petric M (1997) Characterization of torovirus from human fecal specimens. Virology 239: 158- 168

34 Woode GN, Reed DE, Runnels PL, Herrig MA, Hill HT (1982) Studies with an unclassified virus isolated from diarrhoeic calves. Vet Microbiol 7: 221-240

35 Beards GM, Hall C, Green J, Flewett TH, Lamouliatte F, Du Pasquier P (1984) An enveloped virus in stools of children and adults with gastroenteritis that resembles the Breda virus of calves. Lancet 1:1050-1052

36 Rottier PJM (1995) The coronavirus membrane glycoprotein. In: Siddell SG (ed): The Coronaviridae. Plenum Press, New York and London, 115-139

37 Laude H, Masters PS (1995) The coronavirus nucleocapsid protein. In: Siddell SG (ed): The Coronaviridae. Plenum Press, New York and London, 141-163

38 Siddell SG (1995) The small-membrane protein. In: Siddell SG (ed): The Coronaviridae. Plenum, Press, New York and London, 181-189

39 Bos EC, Luytjes W, van der Meulen HV, Koerten HK, Spaan WJ (1996) The production of recombinant infectious DI-particles of a murine coronavirus in the absence of helper virus. Virology 218: 52-60

40 Vennema H, Godeke GJ, Rossen JWA, Voorhout WF, Horzinek MC, Opstelten DJE, Rottier PJM (1996) Nucleocapsid-independent assembly of coronaviruslike particles by co-expression of viral envelope protein genes. Embo $J$ 15: 2020-2028

41 Cavanagh D, Davis PJ, Pappin DJC (1986) Coronavirus IBV glycopolypeptides: locational studies using proteases and saponin, a membrane permeabiliser. Virus Res 4: 145-156

42 Rottier P, Armstrong J, Meyer DI (1985) Signal recognition particle-dependent insertion of coronavirus E1, an intracellular membrane glycoprotein. $J$ Biol Chem 260: 4648-4652

43 Risco C, Anton IM, Sune C, Pedregosa AM, Martin-Alonso JM, Parra F, Carrascosa JL, Enjuanes L (1995) Membrane protein molecules of transmissible gastroenteritis coronavirus also expose the carboxy-terminal region on the external surface of the virion. $J$ Virol 69: 5269-5277 
44 Risco C, Anton IM, Enjuanes L, Carrascosa JL (1996) The transmissible gastroenteritis coronavirus contains a spherical core shell consisting of $\mathrm{M}$ and $\mathrm{N}$ proteins. J Virol 70: 4773-4777

45 Escors D, Camafeita E, Ortego J, Laude H, Enjuanes L (2001) Organization of two transmissible gastroenteritis coronavirus membrane protein topologies within the virion and core. J Virol 75: 12228-12240

46 Escors D, Ortego J, Laude H, Enjuanes L (2001) The membrane M protein carboxy terminus binds to transmissible gastroenteritis coronavirus core and contributes to core stability. J Virol 75: 1312-1324

47 Kuo L, Masters PS (2002) Genetic evidence for a structural interaction between the carboxy termini of the membrane and nucleocapsid proteins of mouse hepatitis virus. $J$ Virol 76: 4987-4999

48 de Haan CA, Kuo L, Masters PS, Vennema H, Rottier PJ (1998) Coronavirus particle assembly: primary structure requirements of the membrane protein. $J$ Virol 72: 6838-6850

49 de Haan CA, Vennema H, Rottier PJ (2000) Assembly of the coronavirus envelope: homotypic interactions between the M proteins. $J$ Virol 74: 4967-4978

50 Godeke GJ, de Haan CA, Rossen JW, Vennema H, Rottier PJ (2000) Assembly of spikes into coronavirus particles is mediated by the carboxy-terminal domain of the spike protein. J Virol 74: 1566-1571

51 Opstelten DJ, Raamsman MJ, Wolfs K, Horzinek MC, Rottier PJ (1995) Envelope glycoprotein interactions in coronavirus assembly. J Cell Biol 131: 339-349

52 de Haan CA, Smeets M, Vernooij F, Vennema H, Rottier PJ (1999) Mapping of the coronavirus membrane protein domains involved in interaction with the spike protein. $J$ Virol 73: 7441-7452

53 de Haan CA, Roestenberg P, de Wit M, de Vries AA, Nilsson T, Vennema H, Rottier PJ (1998) Structural requirements for O-glycosylation of the mouse hepatitis virus membrane protein. J Biol Chem 273: 29905-29914

54 Godet M, L'Haridon R, Vautherot J-F, Laude H (1992) TGEV corona virus ORF-4 encodes a membrane protein that is incorporated into virions. Virology 188: 666-675

55 Corse E, Machamer CE (2000) Infectious bronchitis virus E protein is targeted to the golgi complex and directs release of virus-like particles. $J$ Virol 74: 4319-4326

56 Raamsman MJ, Locker JK, de Hooge A, de Vries AA, Griffiths G, Vennema H, Rottier PJ (2000) Characterization of the coronavirus mouse hepatitis virus strain A59 small membrane protein E. J Virol 74: 2333-2342

57 Brian DA, Hogue BG, Kienzle TE (1995) The coronavirus hemagglutinin esterase glycoprotein. In: Siddell SG (ed): The Coronaviridae. Plenum Press, New York and London, 165-179

58 Vlasak R, Luytjes W, Spaan W, Palese P (1988) Human and bovine coronaviruses recognise sialic acid-containing receptors similar to those of influenza C viruses. Proc Natl Acad Sci USA 85: 4526-4529 
59 Snijder EJ, Horzinek MC (1995) The molecular biology of Toroviruses. In: Siddell SG (ed): The Coronaviridae. Plenum Press, New York and London, 219-238

60 Pedersen NC, Ward I, Mengeling WL (1978) Antigenic relationships of feline infectious peritonitis virus to coronavirus of other species. Arch Virol 58: 45-53

61 Gonzalez JM, Gomez-Puertas P, Cavanagh D, Gorbalenya AE, Enjuanes L (2003) A comparative sequence analysis to revise the current taxonomy of the family Coronaviridae. Arch Virol 148: 2207-2235

62 Duarte M, Tobler K, Bridgen A, Rasschaert D, Ackermann M, Laude H (1994) Sequence analysis of the porcine epidemic diarrhea virus genome between the nucleocapsid and spike protein genes reveals a polymorphic ORF. Virology 198: 466-476

63 Correa I, Jimenez G, Sune C, Bullido MJ, Enjuanes L (1988) Antigenic structure of the E2 glycoprotein from transmissible gastroenteritis coronavirus. Virus Res 10: 77-93

64 Laude H, Chapsal JM, Gelfi J, Labiau S, Grosclaude J (1986) Antigenic structure of transmissible gastroenteritis virus. I. Properties of monoclonal antibodies directed against virion proteins. J Gen Virol 67: 119-130

65 Sanchez CM, Jimenez G, Laviada MD, Correa I, Sune C, Bullido M, Gebauer F, Smerdou C, Callebaut P, Escribano JM et al (1990) Antigenic homology among coronaviruses related to transmissible gastroenteritis virus. Virology 174: $410-417$

66 Smits SL, Lavazza A, Matiz K, Horzinek MC, Koopmans MP, de Groot RJ (2003) Phylogenetic and evolutionary relationships among torovirus field variants: evidence for multiple intertypic recombination events. $J$ Virol 77: 95679577

67 de Vries AAF, Horzinek MC, Rottier PJM, de Groot RJ (1997) The genome organisation of the nidovirales: similarities and differences between arteri-, toro- and coronaviruses. Seminars in Virol 8: 33-47

68 Sapats SI, Ashton F, Wright PJ, Ignjatovic J (1996) Novel variation in the N protein of avian infectious bronchitis virus. Virology 226: 412-417

69 Dalton K, Casais R, Shaw K, Stirrups K, Evans S, Britton P, Brown TD, Cavanagh D (2001) cis-Acting sequences required for coronavirus infectious bronchitis virus defective-RNA replication and packaging. $J$ Virol 75: 125-133

70 Ortego J, Sola I, Almazan F, Ceriani JE, Riquelme C, Balasch M, Plana J, Enjuanes L (2003) Transmissible gastroenteritis coronavirus gene 7 is not essential but influences in vivo virus replication and virulence. Virology 308: $13-22$

71 Sola I, Alonso S, Zuniga S, Balasch M, Plana-Duran J, Enjuanes L (2003) Engineering the transmissible gastroenteritis virus genome as an expression vector inducing lactogenic immunity. J Virol 77: 4357-4369

72 Ontiveros E, Kuo L, Masters PS, Perlman S (2001) Inactivation of expression of gene 4 of mouse hepatitis virus strain JHM does not affect virulence in the murine CNS. Virology 289: 230-238

73 Casais R, Thiel V, Siddell SG, Cavanagh D, Britton P (2001) Reverse genetics 
system for the avian coronavirus infectious bronchitis virus. J Virol 75: 1235912369

74 Snijder EJ, Bredenbeek PJ, Dobbe JC, Thiel V, Ziebuhr J, Poon LL, Guan Y, Rozanov M, Spaan WJ, Gorbalenya AE (2003) Unique and conserved features of genome and proteome of SARS-coronavirus, an early split-off from the coronavirus group 2 lineage. J Mol Biol 331: 991-1004

75 Sola I, Alonso S, Zuniga S, Balasch M, Plana-Duran J, Enjuanes L (2003) Engineering the transmissible gastroenteritis virus genome as an expression vector inducing lactogenic immunity. $J$ Virol 77: 4357-69

76 Thiel V, Ivanov KA, Putics A, Hertzig T, Schelle B, Bayer S, Weissbrich B, Snijder EJ, Rabenau H, Doerr HW, Gorbalenya AE, Ziebuhr J (2003) Mechanisms and enzymes involved in SARS coronavirus genome expression. $J$ Gen Virol 84: 2305-15

77 Guan Y, Zheng BJ, He YQ, Liu XL, Zhuang ZX, Cheung CL, Luo SW, Li PH, Zhang LJ, Guan YJ et al (2003) Isolation and characterization of viruses related to the SARS coronavirus from animals in southern China. Science 302: 276-278

78 Popova R, Zhang X (2002) The spike but not the hemagglutinin/esterase protein of bovine coronavirus is necessary and sufficient for viral infection. Virology 294: 222-236

79 Schultze B, Wahn K, Klenk HD, Herrler G (1991) Isolated HE-protein from hemagglutinating encephalomyelitis virus and bovine coronavirus has receptor-destroying and receptor-binding activity. Virology 180: 221-228

80 Cavanagh D (2003) Severe acute respiratory syndrome vaccine development: experiences of vaccination against avian infectious bronchitis coronavirus. Avian Pathol 32: 567-582

81 Tan K, Zelus BD, Meijers R, Liu JH, Bergelson JM, Duke N, Zhang R, Joachimiak A, Holmes KV, Wang JH (2002) Crystal structure of murine sCEACAM1a[1,4]: a coronavirus receptor in the CEA family. Embo $J$ 21: 2076-2086

82 Chen DS, Asanaka M, Chen FS, Shively JE, Lai MM (1997) Human carcinoembryonic antigen and biliary glycoprotein can serve as mouse hepatitis virus receptors. J Virol 71: 1688-1691

83 Rao PV, Kumari S, Gallagher TM (1997) Identification of a contiguous 6residue determinant in the MHV receptor that controls the level of virion binding to cells. Virology 229: 336-348

84 Miura HS, Nakagaki K, Taguchi F (2004) N-terminal domain of the murine coronavirus receptor CEACAM1 is responsible for fusogenic activation and conformational changes of the spike protein. $J$ Virol 78: 216-223

85 Schickli JH, Zelus BD, Wentworth DE, Sawicki SG, Holmes KV (1997) The murine coronavirus mouse hepatitis virus strain A59 from persistently infected murine cells exhibits an extended host range. J Virol 71: 9499-9507

86 Suzuki H, Taguchi F (1996) Analysis of receptor-binding site of murine coronavirus spike protein. J Virol 70: 2632-2636

87 Gallagher TM (1997) A role for naturally occurring variation of the murine 
coronavirus spike protein in stabilizing association with the cellular receptor. $J$ Virol 71: 3129-3137

88 Tresnan DB, Levis R, Holmes KV (1996) Feline aminopeptidase N serves as a receptor for feline, canine, porcine, and human coronaviruses in serogroup I. $J$ Virol 70: 8669-8674

89 Benbacer L, Kut E, Besnardeau L, Laude H, Delmas B (1997) Interspecies aminopeptidase- $\mathrm{N}$ chimeras reveal species-specific receptor recognition by canine coronavirus, feline infectious peritonitis virus, and transmissible gastroenteritis virus. J Virol 71: 734-737

90 Kolb AF, Maile J, Heister A, Siddell SG (1996) Characterization of functional domains in the human coronavirus HCV 229E receptor. J Gen Virol 77: 2515-2521

91 Kolb AF, Hegyi A, Siddell SG (1997) Identification of residues critical for the human coronavirus 229E receptor function of human aminopeptidase N. J Gen Virol 78: 2795-2802

92 Wentworth DE, Holmes KV (2001) Molecular determinants of species specificity in the coronavirus receptor aminopeptidase $\mathrm{N}$ (cd13): influence of $\mathrm{n}$ linked glycosylation. J Virol 75: 9741-9752

93 Lachance C, Arbour N, Cashman NR, Talbot PJ (1998) Involvement of aminopeptidase $\mathrm{N}$ (CD13) in infection of human neural cells by human coronavirus 229E. J Virol 72: 6511-6519

94 Hohdatsu T, Izumiya Y, Yokoyama Y, Kida K, Koyama H (1998) Differences in virus receptor for type I and type II feline infectious peritonitis virus. Arch Virol 143: 839-850

95 Herrewegh AAPM, Smeenk I, Horzinek MC, Rottier PJM, deGroot RJ (1998) Feline coronavirus type II strains 79-1683 and 79-1146 originate from a double recombination between feline coronavirus type I and canine coronavirus. $J$ Virol 72: 4508-4514

96 Bonavia A, Zelus BD, Wentworth DE, Talbot PJ, Holmes KV (2003) Identification of a receptor-binding domain of the spike glycoprotein of human coronavirus HCoV-229E. J Virol 77: 2530-2538

97 Li W, Moore MJ, Vasilieva N, Sui J, Wong SK, Berne MA, Somasundaran M, Sullivan JL, Luzuriaga K, Greenough TC, Choe H, Farzan M (2003) Angiotensin-converting enzyme 2 is a functional receptor for the SARS coronavirus. Nature 426: 450-454

98 Xiao X, Chakrabarti S, Dimitrov AS, Gramatikoff K, Dimitrov DS (2003) The SARS-CoV S glycoprotein: expression and functional characterization. Biochem Biophys Res Comm 312: 1159-1164

99 Schwegmann-Wessels C, Zimmer G, Schröder B, Breves G, Herrler G (2003) Binding of transmissible gastroenteritis coronavirus to brush border membrane sialoglycoproteins. J Virol 77: 11846-11848

100 Schultze B, Herrler G (1992) Bovine coronavirus uses N-acetyl-9-O-acetylneuraminic acid as a receptor determinant to initiate the infection of cultured cells. J Gen Virol 73: 901-906

101 Krempl C, Ballesteros M, Zimmer G, Enjuanes L, Klenk H, Herrler G (2000) 
Characterization of the sialic acid binding activity of transmissible gastroenteritis coronavirus by analysis of haemagglutination-deficient mutants. J Gen Virol 81: 489-496

102 Schwegmann-Wessels C, Zimmer G, Laude H, Enjuanes L, Herrler G (2002) Binding of transmissible gastroenteritis coronavirus to cell surface sialoglycoproteins. J Virol 76: 99

103 Schultze B, Cavanagh D, Herrler G (1992) Neuraminidase treatment of avian infectious bronchitis coronavirus reveals a hemagglutinating activity that is dependent on sialic acid-containing receptors on erythrocytes. Virology 189: 792-794

104 De Groot RJ, Van Leen RW, Dalderup MJ, Vennema H, Horzinek MC, Spaan WJ (1989) Stably expressed FIPV peplomer protein induces cell fusion and elicits neutralizing antibodies in mice. Virology 171: 493-502

105 Grosse B, Siddell SG (1994) Single amino acid changes in the S2 subunit of the MHV surface glycoprotein confer resistance to neutralization by S1 subunitspecific monoclonal antibody. Virology 202: 814-824

106 Pfleiderer M, Routledge E, Siddell SG (1990) Functional analysis of the coronavirus MHV-JHM surface glycoproteins in vaccinia virus recombinants. $A d v$ Exp Med Biol 276: 21-31

107 Keck JG, Soe LH, Makino S, Stohlman SA, Lai MMC (1988) RNA recombination of murine coronaviruses: recombination between fusion positive MHVA59 and fusion negative MHV-2. J Virol 62: 1989-1998

108 Yoo D, Parker MD, Song J, Cox GJ, Deregt D, Babiuk LA (1991) Structural analysis of the conformational domains involved in neutralisation of bovine coronavirus using deletion mutants of the spike glycoprotein S1 subunit expressed by recombinant baculoviruses. Virology 183: 91-98

109 Luo ZL, Weiss SR (1998) Roles in cell-to-cell fusion of two conserved hydrophobic regions in the murine coronavirus spike protein. Virology 244: 483-494

110 Britton P (1991) Coronavirus motif. Nature 353: 394

111 Gallagher TM, Escarmis C, Buchmeier MJ (1991) Alteration of the $\mathrm{pH}$ dependence of coronavirus induced cell fusion - Effect of mutations in the spike glycoprotein. J Virol 65: 1916-1928

112 Routledge E, Stauber R, Pfleiderer M, Siddel SG (1991) Analysis of murine coronavirus surface glycoprotein functions by using monoclonal antibodies. $J$ Virol 65: 254-262

113 Luo Z, Matthews AM, Weiss SR (1999) Amino acid substitutions within the leucine zipper domain of the murine coronavirus spike protein cause defects in oligomerization and the ability to induce cell-to-cell fusion. $J$ Virol 73: 8152-8159

114 Luo Z, Weiss SR (1998) Roles in cell-to-cell fusion of two conserved hydrophobic regions in the murine coronavirus spike protein. Virology 244: 483-494

115 Bosch BJ, van der Zee R, de Haan CAM, Rottier PJM (2003) The coronavirus spike protein is a class I virus fusion protein: structural and functional characterization of the fusion care complex. $J$ Virol 77: 8801-8811 
116 Luytjes W, Geerts D, Posthumus W, Meloen R, Spaan W (1989) Amino acid sequence of a conserved neutralizing epitope of murine coronaviruses. $J$ Virol 63: 1408-1412

117 Routledge E, Stauber R, Pfleiderer M, Siddell SG (1991) Analysis of murine coronavirus surface glycoprotein functions by using monoclonal antibodies. $J$ Virol 65: 254-262

118 Kooi C, Cervin M, Anderson R (1991) Differentiation of acid-pH-dependent and acid-pH-nondependent entry pathways for mouse hepatitis virus. Virology 180: 108-119

119 Weismiller DG, Sturman LS, Buchmeier MJ, Fleming JO, Holmes KV (1990) Monoclonal-antibodies to the peplomer glycoprotein of coronavirus mouse hepatitis-virus identify 2-subunits and detect a conformational change in the subunit released under mild alkaline conditions. $J$ Virol 64: 3051-3055

120 Li D, Cavanagh D (1992) Coronavirus IBV-induced membrane fusion occurs at near-neutral pH. Arch Virol 122: 307-316

121 Tsai JC, de Groot L, Pinon JD, Iacono KT, Phillips JJ, Seo SH, Lavi E, Weiss SR (2003) Amino acid substitutions within the heptad repeat domain 1 of murine coronavirus spike protein restrict viral antigen spread in the central nervous system. Virology 312: 369-380

122 Zelus BD, Schickli JH, Blau DM, Weiss SR, Holmes KV (2003) Conformational changes in the spike glycoprotein of murine coronavirus are induced at 37 degrees $\mathrm{C}$ either by soluble murine CEACAM1 receptors or by $\mathrm{pH} 8 . J$ Virol 77: 830-840

123 Stauber R, Pfleiderer M, Siddell S (1993) Proteolytic cleavage of the murine coronavirus surface glycoprotein is not required for its fusion activity. Adv Exp Med Biol 342: 165-170

124 Taguchi F (1993) Fusion formation by the uncleaved spike protein of murine coronavirus JHMV varient cl-2. J Virol 67: 1195-1202

125 Gombold JL, Hingley ST, Weiss SR (1993) Fusion-defective mutants of mouse hepatitis virus A59 contain a mutation in the spike protein cleavage signal. $J$ Virol 67: 4504-4512

126 Thiel V, Herold J, Schelle B, Siddell SG (2001) Viral replicase gene products suffice for coronavirus discontinuous transcription. J Virol 175: 6676-6681

127 Ziebuhr J, Siddell SG (1999) Processing of the human coronavirus 229E replicase polyproteins by the virus-encoded 3C-like proteinase: Identification of proteolytic products and cleavage sites common to pp1a and pp1ab. J Virol 73: 177-185

128 Brierley I, Digard P, Inglis SC (1989) Characterization of an efficient coronavirus ribosomal frameshifting signal - requirement for an RNA pseudoknot. Cell 57: 537-547

129 Brierley I (1995) Ribosomal frameshifting on viral RNAs. J Gen Virol 76: 1885-1892

130 Makino S, Joo M, Makino JK (1991) A system for study of coronavirus mRNA synthesis: a regulated, expressed subgenomic defective interfering RNA results from intergenic site insertion. J Virol 65: 6031-6041 
131 van der Most RG, de Groot RJ, Spaan WJM (1994) Subgenomic RNA synthesis directed by a synthetic defective interfering RNA of mouse hepatitis virus: a study of coronavirus transcription initiation. $J$ Virol 68: 3656-3666

132 van Marle G, Dobbe JC, Gultyaev AP, Luytjes W, Spaan WJ, Snijder EJ (1999) Arterivirus discontinuous mRNA transcription is guided by base pairing between sense and antisense transcription-regulating sequences. Proc Natl Acad Sci USA 96: 12056-12061

133 Alonso S, Izeta A, Sola I, Enjuanes L (2002) Transcription regulatory sequences and mRNA expression levels in the coronavirus transmissible gastroenteritis virus. $J$ Virol 76: 1293-1308

134 van Vliet AL, Smits SL, Rottier PJ, de Groot RJ (2002) Discontinuous and non-discontinuous subgenomic RNA transcription in a nidovirus. Embo $J$ 21: 6571-80

135 Fischer F, Peng D, Hingley ST, Weiss SR, Masters PS (1997) The internal open reading frame within the nucleocapsid gene of mouse hepatitis virus encodes a structural protein that is not essential for viral replication. J Virol 71: 996-1003

136 Senanayake SD, Hofmann MA, Maki JL, Brian DA (1992) The nucleocapsid protein gene of bovine coronavirus is bicistronic. $J$ Virol 66: 5277-5283

137 Liu DX, Inglis SC (1992) Internal entry of ribosomes on a tricistronic mRNA encoded by infectious bronchitis virus. $J$ Virol 66: 6143-6154

138 Thiel V, Siddell SG (1994) Internal ribosome entry in the coding region of murine hepatitis virus mRNA 5. J Gen Virol 75: 3041-3046

139 Le SY, Sonenberg N, Maizel JV Jr (1994) Distinct structural elements and internal entry of ribosomes in mRNA3 encoded by infectious bronchitis virus. Virology 198: 405-411

140 Opstelten DJ, de-Groote P, Horzinek MC, Vennema H, Rottier PJ (1993) Disulfide bonds in folding and transport of mouse hepatitis coronavirus glycoproteins. J Virol 67: 7394-7401

141 Frana MF, Behnke JN, Sturman LS, Holmes KV (1985) Proteolytic cleavage of the E2 glycoprotein of murine coronavirus: host-dependent differences in proteolytic cleavage and cell fusion. J Virol 56: 912-920

142 Cavanagh D, Davis PJ, Pappin DJC, Binns MM, Boursnell MEG, Brown TDK (1986) Coronavirus IBV: partial amino terminal sequencing of spike polypeptide S2 identifies the sequence Arg-Arg-Phe-Arg-Arg at the cleavage site of the spike precursor propolypeptide of IBV strains Beaudette and M41. Virus Res 4: 133-143

143 Luytjes W, Sturman LS, Bredenbeek PJ, Charite J, Van der Zeijst BA, Horzinek MC, Spaan WJ (1987) Primary structure of the glycoprotein E2 of coronavirus MHV-A59 and identification of the trypsin cleavage site. Virology 161:479-487

144 Vennema H, Heijnen L, Zijderveld A, Horzinek MC, Spaan aWJM (1990) Intracellular transport of recombinant coronavirus spike proteins: Implications for virus assembly. J Virol 64: 339-346

145 Schmidt MFG (1982) Acylation of viral spike glycoproteins, a feature of enveloped RNA viruses. Virology 116: 327-338

146 King B, Potts BJ, Brian DA (1985) Bovine coronavirus hemaglutinin protein. Virus Res 2: 53-59 
147 Yoo D, Graham FL, Prevec L, Parker MD, Benko M, Zamb T, Babiuk LA (1992) Synthesis and processing of the haemagglutinin-esterase glycoprotein of bovine coronavirus encoded in the $\mathrm{E} 3$ region of adenovirus. $J$ Gen Virol 73: 2591-2600

148 Cavanagh D (1983) Coronavirus IBV glycopolypeptides: size of their polypeptide moieties and nature of their oligosaccharides. J Gen Virol 64: 1187-1191

149 Stern DF, Sefton BM (1982) Coronavirus proteins: structure and function of the oligosaccharides of the avian infectious bronchitis virus glycoproteins. $J$ Virol 44: 804-812

150 Laude H, Rasschaert D, Huet JC (1987) Sequence and N terminal processing of the transmembrane protein E1 of the coronavirus transmissible gastroenteritis virus. J Gen Virol 68: 1687-1693

151 Kapke PA, Tung FYT, Hogue BG, Brian DA, Woods RD, Wesley RD (1988) The amino terminal signal peptide on the porcine transmissible gastroenteritis coronavirus matrix protein is not an absolute requirement for membrane translocation and glycosylation. Virology 165: 367-376

152 Vennema H, Degroot RJ, Harbour DA, Horzinek MC, Spaan WJM (1991) Primary structure of the membrane and nucleocapsid protein genes of feline infectious peritonitis virus and immunogenicity of recombinant vaccinia viruses in kittens. Virology 181:327-335

153 Garwes DJ, Pocock DH, Pike BV (1976) Isolation of subviral components from transmissible gastroenteritis virus. J Gen Virol 32: 283-294

154 Yu X, Bi W, Weiss SR, Leibowitz JL (1994) Mouse hepatitis virus gene 5b protein is a new virion envelope protein. Virology 202: 1018-1023

155 Escors D, Izeta A, Capiscol C, Enjuanes L (2003) Transmissible gastroenteritis coronavirus packaging signal is located at the $5^{\prime}$ end of the virus genome. $J$ Virol 77: 7890-7902

156 Makino S, Soe LH, Shieh C-K, Lai MMC (1988) Discontinuous transcription generates heterogeneity at the leader fusion sites of coronavirus mRNAs. $J$ Virol 62: 3870-3873

157 La Monica N, Yokomori K, Lai MMC (1992) Coronavirus mRNA synthesis: Identification of novel transcription initiation signals which are differentially regulated by different leader sequences. Virology 188: 402-407

158 Makino S, Lai MMC (1989) Evolution of the 5'-end of genomic RNA of murine coronaviruses during passages in vitro. Virology 169: 227-232

159 Hofmann MA, Chang R-Y, Ku S, Brian DA (1993) Leader-mRNA junction sequences are unique for each subgenomic mRNA species in the bovine coronavirus and remain so throughout persistent infection. Virology 196: 163-171

160 Salanueva IJ, Carrascosa JL, Risco C (1999) Structural maturation of the transmissible gastroenteritis coronavirus. $J$ Virol 73: 7952-64

161 Krijnse-Locker J, Ericsson M, Rottier PJ, Griffiths G (1994) Characterization of the budding compartment of mouse hepatitis virus: evidence that transport from the RER to the Golgi complex requires only one vesicular transport step. J Cell Biol 124: 55-70

162 Escors D, Camafeita E, Ortego J, Laude H, Enjuanes L (2001) Organization of 
two transmissible gastroenteritis coronavirus membrane protein topologies within the virion and core. J Virol 75: 12228-12240

163 Escors D, Ortego J, Laude H, Enjuanes L (2001) The membrane M protein carboxy terminus binds to transmissible gastroenteritis coronavirus core and contributes to core stability. J Virol 75: 1312-1324

164 Fischer F, Stegen CF, Masters PS, Samsonoff WA (1998) Analysis of constructed $\mathrm{E}$ gene mutants of mouse hepatitis virus confirms a pivotal role for E protein in coronavirus assembly. J Virol 72: 7885-7894

165 Corse E, Machamer CE (2002) The cytoplasmic tail of infectious bronchitis virus E protein directs Golgi targeting. $J$ Virol 76: 1273-1284

166 Lim KP, Liu DX (2001) The missing link in coronavirus assembly. Retention of the avian coronavirus infectious bronchitis virus envelope protein in the preGolgi compartments and physical interaction between the envelope and membrane proteins. J Biol Chem 276: 17515-17523

167 Baudoux P, Carrat C, Besnardeau L, Charley B, Laude H (1998) Coronavirus pseudoparticles formed with recombinant $\mathrm{M}$ and $\mathrm{E}$ proteins induce alpha interferon synthesis by leukocytes. $J$ Virol 72: 8636-8643

168 Maeda J, Maeda A, Makino S (1999) Release of coronavirus E protein in membrane vesicles from virus- infected cells and $\mathrm{E}$ protein-expressing cells. Virology 263: 265-272

169 Kuo LL, Masters PS (2003) The small envelope protein E is not essential for murine coronavirus replication. J Virol 77: 4597-4608

170 Kuo L, Masters PS (2003) The small envelope protein e is not essential for murine coronavirus replication. J Virol 77: 4597-4608

171 Risco C, Muntion M, Enjuanes L, Carrascosa JL (1998) Two types of virusrelated particles are found during transmissible gastroenteritis virus morphogenesis. J Virol 72: 4022-4031

172 Lai MMC (1992) Genetic recombination in RNA viruses. Curr Top Microbiol Immunol 176: 21-32

173 Lai MMC, Baric RS, Makino S, Keck JG, Egbert J, Leibowitz JL, Stohlman SA (1985) Recombination between nonsegmented RNA genomes of murine coronaviruses. J Virol 56: 449-456

174 Ballesteros ML, Sanchez CM, Enjuanes L (1997) Two amino acid changes at the N-terminus of transmissible gastroenteritis coronavirus spike protein result in the loss of enteric tropism. Virology 227: 378-388

175 Kottier SA, Cavanagh D, Britton P (1995) Experimental evidence of recombination in coronavirus infectious bronchitis virus. Virology 213: 569-580

176 Cavanagh D, Davis PJ (1988) Evolution of avian coronavirus IBV: sequence of the matrix glycoprotein gene and intergenic region of several serotypes. $J$ Gen Virol 69: 621-629

177 Cavanagh D, Davis PJ, Cook JKA (1992) Infectious-bronchitis virus - evidence for recombination within the massachusetts serotype. Avian Pathol 21: 401-408

178 Jia W, Karaca K, Parrish CR, Naqi SA (1995) A novel variant of avian infectious bronchitis virus resulting from recombination among three different strains. Arch Virol 140: 259-271 
179 Wang L, Junker D, Collisson EW (1993) Evidence of natural recombination within the S1 gene of infectious bronchitis virus. Virology 192: 710-716

180 Wang L, Junker D, Hock L, Ebiary E, Collisson EW (1994) Evolutionary implications of genetic variations in the $\mathrm{S} 1$ gene of infectious bronchitis virus. Virus Res 34: 327-338

181 Herrewegh AA, Smeenk I, Horzinek MC, Rottier PJ, de Groot RJ (1998) Feline coronavirus type II strains 79-1683 and 79-1146 originate from a double recombination between feline coronavirus type I and canine coronavirus. $J$ Virol 72: 4508-4514

182 Snijder EJ, Denboon JA, Horzinek MC, Spaan WJM (1991) Comparison of the genome organization of toroviruses and coronaviruses - evidence for two nonhomologous RNA recombination events during berne virus evolution. Virology 180: 448-452

183 Adzhar AB, Shaw K, Britton P, Cavanagh D (1995) Avian infectious bronchitis virus: differences between 793/B and other strains. Vet Rec 136: 548

184 Kingham BF, Keeler CL Jr, Nix WA, Ladman BS, Gelb J Jr (2000) Identification of avian infectious bronchitis virus by direct automated cycle sequencing of the S-1 gene. Avian Dis 44: 325-335

185 Adzhar A, Gough RE, Haydon D, Shaw K, Britton P, Cavanagh D (1997) Molecular analysis of the 793/B serotype of infectious bronchitis virus in Great Britain. Avian Pathol 26: 625-640

186 Gelb J, Keeler CL, Nix WA, Rosenberger JK, Cloud SS (1997) Antigenic and S-1 genomic characterization of the Delaware variant serotype of infectious bronchitis virus. Avian Dis 41: 661-669

187 Sapats SI, Ashton F, Wright PJ, Ignjatovic J (1996) Sequence analysis of the S1 glycoprotein of infectious bronchitis viruses: Identification of a novel genotypic group in Australia. J Gen Virol 77: 413-418

188 Cavanagh D, Mawditt K, Sharma M, Drury SE, Ainsworth HL, Britton P, Gough RE (2001) Detection of a coronavirus from turkey poults in Europe genetically related to infectious bronchitis virus of chickens. Avian Pathol 30: 355-368

189 Cavanagh D, Mawditt K, Welchman DdB, Britton P, Gough RE (2002) Coronaviruses from pheasants (Phasianus colchicus) are genetically closely related to coronaviruses of domestic fowl (infectious bronchitis virus) and turkeys. Avian Pathol 31: 181-193

190 Cavanagh D, Davis PJ, Cook JKA, Li D, Kant A, Koch G (1992) Location of the amino acid differences in the $\mathrm{S} 1$ spike glycoprotein subunit of closely related serotypes of infectious bronchitis virus. Avian Pathol 21: 33-43

191 Cook JKA (1984) The classification of new serotypes of infectious bronchitis virus isolated from poultry flocks in Britain between 1981 and 1983. Avian Pathol 13: 733-741

192 Cook JKA, Huggins MB (1986) Newly isolated serotypes of infectious bronchitis virus: their role in disease. Avian Pathol 15: 129-138

193 Cavanagh D, Ellis MM, Cook JKA (1997) Relationship between sequence variation in the $\mathrm{S} 1$ spike protein of infectious bronchitis virus and the extent of cross-protection in vivo. Avian Pathol 26: 63-74 
194 Cavanagh D, Davis PJ, Mockett AP (1988) Amino acids within hypervariable region 1 of avian coronavirus IBV (Massachusetts serotype) spike glycoprotein are associated with neutralization epitopes. Virus Res 11: 141-150

195 Kant A, Koch G, van Roozelaar DJ, Kusters JG, Poelwijk FAJ, van der Zeijst BAM (1992) Location of antigenic sites defined by neutralising monoclonal antibodies on the $\mathrm{S} 1$ avian infectious bronchitis virus glycopolypeptide. J Gen Virol 73: 591-596

196 Koch G, Hartog L, Kant A, van Roozelaar DJ (1990) Antigenic domains of the peplomer protein of avian infectious bronchitis virus: correlation with biological function. J Gen Virol 71: 1929-1935

197 Suzuki H, Taguchi F (1996) Analysis of the receptor-binding site of murine coronavirus spike protein. J Virol 70: 2632-2636

198 Britton P, Mawditt KL, Page KW (1991) The cloning and sequencing of the virion protein genes from a British isolate of porcine respiratory coronavirus: comparison with transmissible gastroenteritis virus genes. Virus Res 21: 181-198

199 Enjuanes L, van der Zeijst BAM (1995) Molecular basis of transmissible gastroenteritis virus epidemiology. In: Siddell SG (ed): The Coronaviridae. Plenum Press, New York and London, 337-376

200 Garwes DJ (1995) Pathogenesis of the porcine coronaviruses. In: Siddell SG (ed): The Coronaviridae. Plenum Press, New York and London, 377-388

201 Myint SH (1995) Human coronavirus infections. In: Siddell SG (ed): The Coronaviridae. Plenum Press, New York, 389-402

202 Zhang XM, Herbst W, Kousoulas KG, Storz J (1994) Biological and genetic characterization of a hemagglutinating coronavirus isolated from a diarrhoeic child. J Med Virol 44: 152-161

203 Erles K, Toomey C, Brooks HW, Brownlie J (2003) Detection of a group 2 coronavirus in dogs with canine infectious respiratory disease. Virology 310: 216-223

204 Ismail MM, Cho KO, Ward LA, Saif LJ, Saif YM (2001) Experimental bovine coronavirus in turkey poults and young chickens. Avian Dis 45: 157-163

205 Woods RD, Wesley RD (1992) Seroconversion of pigs in contact with dogs exposed to canine coronavirus. Can J Vet Res 56: 78-80

206 Fouchier RA, Kuiken T, Schutten M, Van Amerongen G, Van Doornum GJ, Van Den Hoogen BG, Peiris M, Lim W, Stohr K, Osterhaus AD (2003) Aetiology: Koch's postulates fulfilled for SARS virus. Nature 423: 240

207 Martina BE, Haagmans BL, Kuiken T, Fouchier RA, Rimmelzwaan GF, Van Amerongen G, Peiris JS, Lim W, Osterhaus AD (2003) Virology: SARS virus infection of cats and ferrets. Nature 425: 915

208 Cavanagh D, Naqi S (2003) Infectious bronchitis. In: Saif YM, Barnes HJ, Glisson JR, Fadly AM, McDougald LR, Swayne DE (eds): Diseases of Poultry. Blackwell, Ames, Iowa, vol 11, 101-119

209 Cook JKA, Mockett APA (1995) Epidemiology of infectious bronchitis virus. In: Siddell SG (ed): The Coronaviridae. Plenum Press, New York and London, 317-335 
210 Hirano N, Goto N, Ogawa T, Ono K, Murakani T, Fukiwara K (1980) Hydrocephalus in suckling rats infected intracerebrally with mouse hepatitis virus MHV-A59. Microbiol Immunol 24: 825

211 de Groot RJ, Horzinek MC (1995) Feline infectious peritonitis. In: Siddell SG (ed): The Coronaviridae. Plenum Press, New York and London, 293-315

212 Addie DD, Jarrett O (2001) Use of a reverse-transcriptase polymerase chain reaction for monitoring the shedding of feline coronavirus by healthy cats. Vet Rec 148: 649-53.

213 Addie DD, Schaap IA, Nicolson L, Jarrett O (2003) Persistence and transmission of natural type I feline coronavirus infection. J Gen Virol 84: 2735-2744

214 Chen BY, Hosi S, Itakura C (1996) Histopathology and immunohistochemistry of renal lesions due to an infectious bronchitis virus in chicks. Avian Pathol 25: 269-283

215 Chen BY, Itakura C (1996) Cytopathology of chick renal epithelia cells experimentally infected with avian infectious bronchitis virus. Avian Pathol 25: 675-690

216 Chen BY, Itakura C (1996) Cytopathology of chick renal epithelial cells experimentally infected with avian infectious bronchitis virus. Avian Pathol 25: 675-690

217 Pensaert M, Lambrechts C (1994) Vaccination of chickens against a Belgian nephropathogenic strain of infectious bronchitis virus B1648 using attenuated homologous and heterologous strains. Avian Pathol 23: 631-641

218 Yu L, Jiang Y, Low S, Wang Z, Nam SJ, Liu W, Kwangac J (2001) Characterization of three infectious bronchitis virus isolates from China associated with proventriculus in vaccinated chickens. Avian Dis 45: 416-424

219 Dales S, Anderson R (1995) Pathogenesis and diseases of the central nervous system caused by murine coronaviruses. In: Siddell SG (ed): The Coronaviridae. Plenum Press, New York and London, 257-292

220 Stohlman SA, Hinton DR (2001) Viral induced demyelination. Brain Pathol 11: 92-106

221 Matthews AE, Weiss SR, Paterson Y (2002) Murine hepatitis virus - a model for virus-induced CNS demyelination. $J$ Neurovirol 8: 76-85

222 Arbour N, Day R, Newcombe J, Talbot PJ (2000) Neuroinvasion by human respiratory coronaviruses. $J$ Virol 74: 8913-8921

223 Stewart JN, Mounir S, Talbot PJ (1992) Human coronavirus gene expression in the brains of multiple sclerosis patients. Virology 191: 502-505

224 Dessau RB, Lisby G, Frederiksen JL (2001) Coronaviruses in brain tissue from patients with multiple sclerosis. Acta Neuropathol (Berl) 101: 601-604

225 Arbour N, Cote G, Lachance C, Tardieu M, Cashman NR, Talbot PJ (1999) Acute and persistent infection of human neural cell lines by human coronavirus OC43. J Virol 73: 3338-3350

226 Enjuanes L, Smerdou C, Sanchez CM, Sune C, Kelly S, Curtiss R 3rd, Torres JM (1995) Induction of transmissible gastroenteritis coronavirus specific immune responses using vectors with enteric tropism. Adv Exp Med Biol $1535-1541$ 
227 Peiris J, Lai S, Poon L, Guan Y, Yam L, Lim W, Nicholls J, Yee W, Yan W, Cheung $\mathrm{M}$ et al (2003) Coronavirus as a possible cause of severe acute respiratory syndrome. Lancet 361: 1319-1325

228 Hodgson T, Casais R, Dove B, Britton P, Cavanagh D (2004) Recombinant infectious bronchitis coronavirus Beaudette with the spike protein gene of the pathogenic M41 strain remains attenuated but induces protective immunity. $J$ Virol 78: 13804-13811

229 Casais R, Dove B, Cavanagh D, Britton P (2003) Recombinant avian infectious bronchitis virus expressing a heterologous spike gene demonstrates that the spike protein is a determinant of cell tropism. $J$ Virol 77: 9084-9089

230 Sanchez CM, Izeta A, Sanchez-Morgado JM, Alonso S, Sola I, Balasch M, Plana-Duran J, Enjuanes L (1999) Targeted recombination demonstrates that the spike gene of transmissible gastroenteritis coronavirus is a determinant of its enteric tropism and virulence. J Virol 73: 7607-7618

231 Leparc-Goffart I, Hingley ST, Chua MM, Jiang X, Lavi E, Weiss SR (1997) Altered pathogenesis of a mutant of the murine coronavirus MHV-A59 is associated with a Q159L amino acid substitution in the spike protein. Virology 239: $1-10$

232 Das Sarma J, Fu L, Tsai JC, Weiss SR, Lavi E (2000) Demyelination determinants map to the spike glycoprotein gene of coronavirus mouse hepatitis virus. J Virol 74: 9206-9213

233 Phillips JJ, Chua MM, Lavi E, Weiss SR (1999) Pathogenesis of chimeric MHV4/MHV-A59 recombinant viruses: the murine coronavirus spike protein is a major determinant of neurovirulence. J Virol 73: 7752-7760

234 Phillips JJ, Chua M, Seo SH, Weiss SR (2001) Multiple regions of the murine coronavirus spike glycoprotein influence neurovirulence. $J$ Neurovirol 7: 421-431

235 Navas S, Seo SH, Chua MM, Sarma JD, Lavi E, Hingley ST, Weiss SR (2001) Murine coronavirus spike protein determines the ability of the virus to replicate in the liver and cause hepatitis. $J$ Virol 75: 2452-2457

236 Jones RC, Ambali AG (1987) Re-excretion of an enterotropic infectious bronchitis virus by hens at point of lay after experimental infection at day old. Vet Rec 120: 617-618

237 Naqi S, Gay K, Patalla P, Mondal S, Liu R (2003) Establishment of persistent avian infectious bronchitis virus infection in antibody-free and antibody-positive chickens. Avian Dis 47: 594-601

238 Darbyshire JH, Peters RW (1984) Sequential development of humoral immunity and assessment of protection in chickens following vaccination and challenge with avian infectious bronchitis virus. Res Vet Sci 37: 77-86

239 Gough RE, Alexander D (1979) Comparison of duration of immunity in chickens infected with a live infectious bronchitis vaccine by three different routes. Res Vet Sci 26: 329-332

240 Cavanagh D, Davis PJ, Darbyshire JH, Peters RW (1986) Coronavirus IBV: virus retaining spike glycopolypeptide $\mathrm{S} 2$ but not $\mathrm{S} 1$ is unable to induce virusneutralizing or haemagglutination-inhibiting antibody, or induce chicken tracheal protection. J Gen Virol 67: 1435-1442 
241 Ignjatovic J, Galli L (1994) The S1 glycoprotein but not the N or M proteins of avian infectious bronchitis virus induces protection in vaccinated chickens. Arch Virol 138: 117-134

242 Song CS, Lee YJ, Lee CW, Sung HW, Kim JH, Mo IP, Izumiya Y, Jang HK, Mikami T (1998) Induction of protective immunity in chickens vaccinated with infectious bronchitis virus S1 glycoprotein expressed by a recombinant baculovirus. J Gen Virol 79: 719-723

243 Macdonald JW, Randall CJ, McMartin DA, Dagless MD, Gazdzinski P (1981) Active and passive immunisation against nephritis induced by an avian infectious bronchitis virus. Avian Pathol 10: 121-129

244 Bumstead N, Huggins MB, Cook JKA (1989) Genetic differences in susceptibility to a mixture of avian infectious bronchitis virus and Escherichia coli. Brit Poultry Sci 30: 39-48

245 Cook JKA, Smith HW, Huggins MB (1986) Infectious bronchitis immunity: its study in chickens experimentally infected with mixtures of infectious bronchitis virus and Escherichia coli. J Gen Virol 67: 1427-1434

246 Otsuki K, Huggins MB, Cook JKA (1990) Comparison of the susceptibility to avian infectious bronchitis virus infection of two inbred lines of White Leghorn chickens. Avian Pathol 19: 467-475

247 Smith HW, Cook JKA, Parsell ZE (1985) The experimental infection of chickens with mixtures of infectious bronchitis virus and Escherichia coli. J Gen Virol 66: 777-786

248 Johnson MA, Pooley C, Ignjatovic J, Tyack SG (2003) A recombinant fowl adenovirus expressing the $\mathrm{S} 1$ gene of infectious bronchitis virus protects against challenge with infectious bronchitis virus. Vaccine 21: 2730-2736

249 Wesseling JG, Godeke G-J, Schijns VECJ, Prevec L, Graham FL, Horzinek MC, Rottier PJM (1993) Mouse hepatitis virus spike and nucleocapsid proteins expressed by adenovirus vectors protect mice against a lethal infection. $J$ Gen Virol 74: 2061-2069

250 Boots AMH, Benaissatrouw BJ, Hesselink W, Rijke E, Schrier C, Hensen EJ (1992) Induction of antiviral immune-responses by immunization with recombinant-DNA encoded avian coronavirus nucleocapsid protein. Vaccine 10: 119-124

251 Seo SH, Wang L, Smith R, Collisson EW (1997) The carboxyl-terminal 120residue polypeptide of infectious bronchitis virus nucleocapsid induces cytotoxic $\mathrm{T}$ lymphocytes and protects chickens from acute infection. $J$ Virol 71: 7889-7894

252 Pei J, Briles WE, Collisson EW (2003) Memory T cells protect chicks from acute infectious bronchitis virus infection. Virology 306: 376-384

253 Collisson EW, Pei J, Dzielawa J, Seo SH (2000) Cytotoxic T lymphocytes are critical in the control of infectious bronchitis virus in poultry. Dev Comp Immunol 24: 187-200

254 Seo SH, Pei J, Briles WE, Dzielawa J, Collisson EW (2000) Adoptive transfer of infectious bronchitis virus primed alphabeta T cells bearing CD8 antigen protects chicks from acute infection. Virology 269: 183-189

255 Korner H, Schliephake A, Winter J, Zimprich F, Lassmann H, Sedgwick J, 
Siddell S, Wege H (1991) Nucleocapsid or spike protein-specific cd4+ lymphocytes-t protect against coronavirus-induced encephalomyelitis in the absence of cd8+ cells-t. J Immunol 147: 2317-2323

256 Bergmann C, McMillan M, Stohlman S (1993) Characterization of the Ldrestricted cytotoxic T-lymphocyte epitope in the mouse hepatitis virus nucleocapsid protein. $J$ Virol 67: 7041-7049

257 Stohlman SA, Kyuwa S, Cohen M, Bergmann C, Polo JM, Yeh J, Anthony R, Keck JG (1992) Mouse hepatitis-virus nucleocapsid protein-specific cytotoxic lymphocytes-t are $\mathrm{L}(\mathrm{d})$ restricted and specific for the carboxy terminus. Virology 189: 217-224

258 Stohlman SA, Kyuwa S, Polo JM, Brady D, Lai MMC, Bergmann C (1993) Characterization of mouse hepatitis virus specific cytotoxic $\mathrm{T}$ cells derived from the central nervous system of mice infected with the JHM strain. $J$ Virol 67: 7050-7059

259 Wege H, Schliephake A, Korner H, Flory E, Wege H (1993) An immunodominant $\mathrm{CD}^{+}{ }^{+} \mathrm{T}$-cell site on the nucleocapsid protein of murine coronavirus contributes to protection against encephalomyelitis. J Gen Virol 74: 1287-1294

260 Nakanaga K, Yamanouchi K, Fuziwara K (1986) Protective effect of monoclonal antibodies on lethal mouse hepatitis virus infection in mice. J Virol 59: 168-171

261 Evermann JF, Heeney JL, McKeirnan AJ, Obrien SJ (1989) Comparative features of a coronavirus isolated from a cheetah with feline infectious peritonitis. Virus Res 13: 15-28

262 Heeney JL, Evermann JF, McKeirnan AJ, Marker-Kraus L, Roelke ME, Bush M, Wildt DE, Meltzer DG, Colly L, Lukas J et al (1990) Prevalence and implications of feline coronavirus infections of captive and free-ranging cheetahs (Acinonyx jubatus). J Virol 64: 1964-1972

263 Cavanagh D, Brian DA, Brinton M, Enjuanes L, Holmes KV, Horzinek MC, Lai MMC, Laude H, Plagemann PGW, Siddell S et al (1994) Revision of the taxonomy of the coronavirus, torovirus and arterivirus genera. Arch Virol 135: 227-237

264 Enjuanes L, Brian D, Cavanagh D, Holmes K, Lai MMC, Laude H, Masters P, Rottier P, Siddell SG, Spaan WJM et al (2000) Coronaviridae. In: van Regenmortel MHV, Fauquet CM, Bishop DHL, Carstens EB, Estes MK, Lemon S, Maniloff J, Mayo M, McGeoch DJ, Pringle CR, Wickner RB (eds): Virus Taxonomy. Classification and Nomenclature of Viruses. Academic Press, San Diego, 835-849

265 Duckmanton L, Luan B, Devenish J, Tellier R, Petric M (1997) Characterization of torovirus from human faecal specimens. Virology 239: 158-168

266 González JM, Gomez-Puertas P, Cavanagh D, Gorbalenya AE, Enjuanes L (2003) Taxonomical relations within the family Coronaviridae based on sequence identity analysis. Arch Virol 148: 2207-2235

267 Daniel C, Talbot PJ (1990) Protection from lethal coronavirus infection by affinity-purified spike glycoprotein of murine hepatitis virus, strain-A59. Virology 174: 87-94 